2005

\title{
Great Expectations' Defeated?: The Trajectory of Collective Bargaining Regimes in Canada and the U.S. Post-NAFTA
}

Eric Tucker

Osgoode Hall Law School of York University, etucker@yorku.ca

Follow this and additional works at: http://digitalcommons.osgoode.yorku.ca/all_papers

\section{Repository Citation}

Tucker, Eric, "Great Expectations' Defeated?: The Trajectory of Collective Bargaining Regimes in Canada and the U.S. Post-NAFTA" (2005). All Papers. Paper 29.

http://digitalcommons.osgoode.yorku.ca/all_papers/29 


\section{Cleveland-Marshall College of Law}

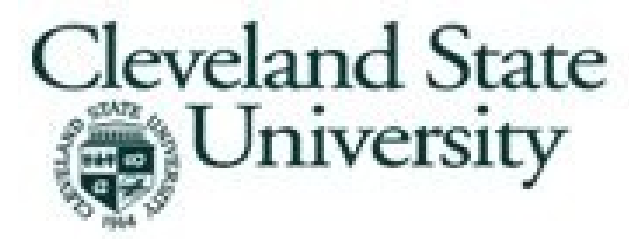

Research Paper 05-110

March 2005

\section{'Great Expectations' Defeated?: The Trajectory of Collective Bargaining Regimes in Canada and the U.S. post-NAFTA}

By

\section{Eric Tucker}

Scholar in Residence, Cleveland-Marshall College of Law 2004-2005

Professor of Law, Osgoode Hall Law School, York University

Working Paper

This paper can be downloaded without charge from the Social Science Research Network electronic library: 


\section{Introduction}

Ironically, the study globalization's impact on the performance of labor markets and labor market regulation has generated a new industry that has provided work to a small army of researchers for more than a decade. ${ }^{1}$ So it was with some trepidation that I decided to join their ranks, even if only for a short tour of duty, especially in light of the sharply contested positions held among these scholars who are drawn from a variety of disciplines and come with sharply divergent normative commitments.

From the beginning of the free-trade era ${ }^{2}$ one contentious area has been the impact of trade liberalization on labor law. Opponents of NAFTA (and some supporters) predicted a regulatory race to the bottom (RTB) would ensue leading to increasingly deregulated labor markets. The result would be weaker collective bargaining laws, lower minimum standards, and a decline in the social wage. In recent years a number of scholars have examined the question in light of more than fifteen years experience under CUFTA and ten under NAFTA and there seems to be a growing consensus that, contrary

1 A crude indicator of the growth of this industry can be gleaned from searches I conducted on two electronic indexes (ASAP Academic - an interdisciplinary index - and the Index to Legal Periodicals and Books) of the term "globalization and labo*r. From the beginning of 1980 (when both indexes begin) to the end of 1989 there were $4(1+3)$ such references. From 1990 to December 6, 2004 there were $1484(508+986)$. I will leave it to economically inclined readers to decide whether the shift of resources into the globalization research industry has increased aggregate welfare.

${ }^{2}$ For the purposes of this paper, the free-trade era begins with the Canada-United States Free Trade Agreement (entered into force 1 January 1989) (CUFTA), incorporated into the North American Free Trade Agreement Between the Government of Canada, the Government of Mexico and the Government of the United States, 17 December 1992, Can. T.S. 1994 No. 2, I.L.M. 289 (entered into force 1 January 1994)(NAFTA). Hereinafter I will just refer to NAFTA unless CUFTA is being discussed separately. 
to those 'great expectations', labor laws in North America have not been significantly weakened. $^{3}$

In this article, I re-examine the effects of NAFTA on collective bargaining law in Canada and the United States. The restriction of my focus to collective bargaining is prudential. In principle a proper assessment of NAFTA's effects should encompass all the strands of labor market regulation, but that is too large a project for an article. The decision to exclude Mexico from this analysis was partly prudential, but also based on the fact that its legal traditions, labor market organizations and institutional arrangements are very different from those prevailing in Canada and the United States, complicating the comparison.

My contribution to the debates comes down to two points. On the one hand, I argue that the emerging consensus understates the impact of NAFTA-style trade liberalization on the legal regulation of collective bargaining because its focus is artificially narrow. In reaching their conclusions, 'new consensus' scholars have looked exclusively at changes in private sector collective bargaining legislation. I argue this produces a misleading picture of the impact of trade liberalization because it omits public

\footnotetext{
${ }^{3}$ For a review of the literature, see Kevin Banks, "Globalization and Labour Standards Second Look at the Evidence,” (2004) 29 Queen's Law Journal 533 (Banks challenges emerging consensus that globalization has no negative impact on labor standards). Also see Michel Gauvin, Labour Legislation in Canada: Major Developments and Trends, 1989-2003 (Ottawa: Labour Law Analysis, Strategic Policy and International Labour Affairs, Labour Program, Human Resources and Development Canada, October 3, 2003); Parbudyal Singh, "NAFTA and Labor: A Canadian Perspective," (2002) Journal of Labor Research 433 (short review of changes in Canadian labor laws and standards largely based on secondary sources from the mid-1990s); Pierre Verge, "How Does Canadian Labour Law Fare in a Global Economy?," (2000) 42 Journal of Industrial Relations 275.
} 
sector collective bargaining and, even more importantly, it fails to consider the impact of trade liberalization on the effectiveness of statutory collective bargaining schemes. If the focus is broadened to include public sector bargaining and labor law's effectiveness, then one finds there has been more labor market deregulation than consensus scholars acknowledge.

On the other hand, I accept that, even after broadening our analytical lens, the downward trajectory of the collective bargaining regime has not been as steep as many RTB theorists predicted. I argue that the model upon which this prediction was based was overly structural and that a more nuanced one is needed. Such a model must better take into account a range of factors that mediate the impact of NAFTA-style trade liberalization on labor market regulation. These mediations occur at the economic level, within the collective bargaining regime itself, and in the external environment that shapes the direction of state action.

The paper is organized as follows. In the remainder of this section, I address some preliminary and methodological issues. In Part II, I present a simple model of the race to the bottom and then suggest an alternative, more nuanced model of the impact of trade liberalization on labor market regulation. In Part III, I use that model to explore developments in the collective bargaining regimes of Canada and the United States. In Part IV I offer some brief concluding observations. 
From the time the idea of a Canada-US free trade agreement was first floated, its affect on labor market regulation was hotly contested. ${ }^{4}$ The debate had both an empirical and a normative dimension. The empirical question was whether, under a free trade agreement that left each party at liberty to change its domestic labor standards (including collective bargaining laws, minimum standards laws, anti-discrimination law, workers' compensation laws, occupational health and safety laws, and unemployment insurance), labor markets would become less regulated. To greatly simplify, critics of the free trade agreements embraced the RTB hypothesis. According to this view, as capital became more mobile it would seek to produce in the lowest cost jurisdiction. Jurisdictions with high labor standards would be threatened with the loss of investment and, therefore, would be under pressure to cut back on them, while jurisdictions seeking to attract new investment would be tempted to lower labor standards. The result would be regulatory competition that would push labor standards lower, unless other forces could be mobilized to counteract the downward pressure. At the very least, supporters of strong labor standards would be put on the defensive, fighting to hold on to their past gains. ${ }^{5}$ Although some supporters of free trade acknowledged that it would lead to less labor market regulation, most supporters this claim, arguing variously that the prisoners'

\footnotetext{
${ }^{4}$ These debates are reviewed by Brian A. Langille, "Canadian Labour Law Reform and Free Trade," (1991) 23 Ottawa Law Review 581, 592-608 and George W. Adams, "The U.S.Canada Free Trade Agreement and Collective Bargaining," (1988) 14 Can.-U.S. Law Journal 41, 46-52.

${ }^{5}$ For example, see Ian Robinson, "How Will the North American Free Trade Agreement Affect Worker Rights in North America?," in Maria Lorena Cook and Harry C. Katz, eds., Regional Integration and Industrial Relations in North America (Ithaca, NY: Institute of Collective Bargaining, New York State School of Industrial and Labor Relations, Cornell University, 1994), 105-131.
} 
dilemma scenario that underpins the RTB analysis did not apply, that progressive competitiveness strategies could yield mutual gains for labor and capital, or that the positive effect of free trade on economic development would promote upward harmonization. ${ }^{6}$

The normative dimension of the debate was launched from the implicit premise that labor market regulation would be weakened under free trade. The question was whether that would be an undesirable outcome. Again, to greatly simplify, for free trade critics, the answer was clearly that weakened labor market regulation would be undesirable since it would undermine labor law's social justice objectives: worker participation and voice achieved through collective bargaining would be undermined, as would protection against low wages, long hours of work, discriminatory treatment, unhealthy and unsafe working conditions, and the risk of income disruption due to injury, illness or unemployment. Supporters of liberalized trade and regulatory competitiveness, on the other hand, viewed the question through the lens of comparative advantage and efficiency. If competition in product markets is a good thing, then so too is competition among producers of regulatory policy. Jurisdictions may choose to have sub-optimal (eg. unduly high) labor standards if that is the will of the electorate, but in a free-trade regime they will have to bear more of its cost (lower investment), as capital exits to jurisdictions with more favorable regulatory regimes. If the threat of capital flight induces voters in otherwise pro-regulatory jurisdictions to choose more optimal (eg. lower) standards that

\footnotetext{
${ }^{6}$ For a useful survey of the competing views, see Morely Gunderson, "Harmonization of Labour Policies under Trade Liberalization,” (1998) 53 Relations Industrielles 24; Brian Langille, "Competing Conceptions of Regulatory Competition in Debates on Trade Liberalization and Labour Standards," in William Bratton et al., eds., International Regulatory Competition and Coordination (Oxford: Claredon, 1996), 479.
} 
give them a comparative advantage, then this is a good outcome. It is just another dimension of achieving net welfare gains through trade based on comparative advantage. Certainly right-wing think tanks that ardently support free trade routinely make the claim that high labor standards, including minimum wage laws and collective bargaining laws, negatively affect competitiveness and, therefore, should be reduced. ${ }^{7}$

In this paper, my focus is on the empirical dimension of the debate rather than the normative, but I want to make one observation on what the normative regulatory competitiveness debate reveals about the goal of NAFTA-style trade liberalization: that whatever else NAFTA may aim to accomplish, it is an "ambitious attempts to enlist external markets to obtain political ends." ${ }^{8}$ Put somewhat differently, NAFTA should be viewed as part and parcel of a larger neo-liberal political project that aims to alter the balance of power between class forces and shift the role of the state from ameliorating the dysfunctional consequences of markets through social democratic or Keynesian welfarist policies to the promotion of global competitiveness. In this way, NAFTA creates a "conditioning framework" that is intended to influence the policy choices of citizens and government. ${ }^{9}$

\footnotetext{
${ }^{7}$ For example, see Jason Clemens and Mark Mullins, "Dangers in Rigid Labour Laws: Ministers Propose Prescriptive Changes to Labour Market Regulation” Online at http://www.fraserinstitute.ca/shared/readmore1.asp?sNav=ed\&id=317 (critique of proposed labor law reforms stating: "These labour reforms are being proposed despite competition from other jurisdictions").

8 Daniel Drache, "Dreaming Trade or Trading Dreams: The Limits of Trade Blocs," in William Bratton et al., eds., International Regulatory Competition and Coordination (Oxford: Clarendon, 1996), 417 at 418.

${ }^{9}$ Roberto Grinspun and Robert Kreklewitch, "Consolidating Neoliberal Reforms: Free Trade as a Conditioning Framework," (1994) 43 Studies in Political Economy 33.
} 
One final preliminary point is that it is difficult to make an overall assessment of the trajectory of Canadian collective bargaining law because constitutional jurisdiction over labor and employment has been held by the courts to rest primarily with the provinces. ${ }^{10}$ As a result, the federal government's Canada Labour Code ${ }^{11}$ applies to about ten percent of the labor force, while the laws of the provinces or territories govern the remaining ninety percent of Canadian workers. In theory it is possible to construct numerical indices that reflect changes in each jurisdiction over a fifteen-year period and then arrive at a quantitative national assessment of the trajectory of Canadian labor law. ${ }^{12}$ I have adopted a different approach that is based on a qualitative assessment of changes in Canada's three largest jurisdictions -- Ontario, British Columbia, and Quebec - which contain about eighty percent of the labor force between them. Mention will be made of developments in other Canadian jurisdictions as appropriate. There is less of a problem with American labor law because of federal preemption in the area of private sector collective bargaining. State and local law, however, largely governs public sector collective bargaining, outside of the federal civil service.

\section{Modeling NAFTA's Impact}

\section{A. The Race to the Bottom Model}

Figure 1 presents a model of the RTB hypothesis. Essentially, it predicts that under trade liberalization a downward regulatory competition will be promoted because

10 Toronto Electric Commissioners v. Snider [1925] A.C. 396.

${ }^{11}$ R.S.C. 1985 , c. L-2.

${ }^{12}$ For an ambitious attempt to create such indices, see Richard N. Block, et al., Labor Standards in the United States and Canada (Kalamazoo: W.E. Upjohn Institute for Employment Research). 
of the interaction between its effects on the economy and on the institutions for regulating the labor market. In terms of economic effects, the argument is that in liberalized trading regimes capital and product mobility is increased. This is accomplished by the removal of tariff and non-tariff barriers to trade and by guaranteeing the security of investor rights against adverse state action. NAFTA clearly accomplished this result (at least in principle) by phasing out remaining tariffs between the member countries and by eliminating the need for various import licenses and other non-tariff barriers. As well, it protects NAFTA investors by guaranteeing national treatment (treatment no less favorable than that given to national investors), most-favored nation status (treatment no less favorable than that given to foreign investors of a third country), and property rights against expropriation or nationalization (or measures having equivalent effect). It also creates an investor-state disputing process that permits NAFTA investors to bring complaints to an international tribunal with binding arbitration powers. ${ }^{13}$

The increased mobility of capital and products enhances competition between employers who are forced to continually seek ways to produce more efficiently lest a lower-cost producer displace them. Labor is one factor of production that will be affected by this intensified competitive struggle. Employers in a more competitive environment will seek to increase labor productivity by lowering unit labor costs. This can be accomplished by reducing the cost of employing a given quantity of labor or by

\footnotetext{
${ }^{13}$ Ian Robinson, "How Will the North American Free Trade Agreement Affect Worker Rights in North America?," in Maria Lorena Cook and Harry C. Katz, eds. Regional Integration and Industrial Relations in North America (Ithaca NY: Institute of Collective Bargaining, N.Y. State School of Industrial and Labor Relations, Cornell University, 1994), 105, 106-108.
} 
increasing the amount produced by that same quantity of labor, or, most likely, by some combination of the two (lower labor costs/higher productivity).

Because capital is mobile, it will move to jurisdictions where it can produce most efficiently. These choices will depend in part on the natural and infrastructural advantages of different locations, but governments will also adopt measures to maximize their attractiveness to existing and prospective investors. Strong, comprehensive, and well-enforced labor standards will not be attractive, as studies have shown that many employers and multinational buyers perceive that higher standards result in competitive disadvantage. ${ }^{14}$ States that have high standards, therefore, will be pressured by employers to lower them, ${ }^{15}$ while states that have weak labor standards will, at the very least, be disinclined to improve them, and, at worst, be driven to reduce them even further to meet the competition from states that are weakening theirs. Workers' organizations will be less able politically to resist labor market deregulation in this environment because of the greater weight of market discipline on state action. As well, their ability to organize and their economic leverage will be reduced by the threat of capital flight. ${ }^{16}$

This model assumes that trade liberalization occurs within a particular institutional framework, one in which regulatory authority over labor markets remains

\footnotetext{
${ }^{14}$ eg. Elliot, Labor Standards.

15 For example, see Guylaine Valée and Jean Charest, "Globalization and the Transformation of State Regulation of Labour: the Case of Recent Amendments to the Quebec Collective Agreement Decrees Act," (2001) 17 International Journal of Comparative Labour Law and Industrial Relations 79

${ }^{16}$ Kate Bronfenbrenner, "Uneasy terrain: The impact of Capital Mobility on Workers, Wages, and Union Organizing," (Washington DC: US Trade Deficit Review Commission, Commissioned Research Paper, 2000).
} 
local while capital is free to move outside the regulation-producing jurisdiction. If different institutional arrangements were created to coordinate the production of labor market standards among jurisdictions, or to create a new global regulation-producing authority then the regulatory competition would end, and the market for labor market standards would cease to operate, or at least be constrained.

What, then, are the institutional arrangements made by NAFTA for labor market regulation? NAFTA itself has little to say on social matters, except in the preamble where the parties resolve to "create new employment opportunities and improve working conditions and living standards in their respective territories" and to "protect, enhance, and enforce basic workers' rights." ${ }^{17}$ These are not, however, enforceable obligations. For this we must turn to the North American Accord on Labor Cooperation (NAALC), ${ }^{18}$ or labor side accord, concluded after NAFTA was signed to fulfill an election promise made by Bill Clinton that such an accord was a prerequisite to U.S. ratification. ${ }^{19}$ NAALC sets out eleven guiding principles that each of the three signatories undertake to promote, subject to each party's domestic law.

1. freedom of association and protection of the right to organize

${ }^{17}$ NAFTA, Preamble, available at http://www.nafta-sec-alena.org

${ }^{18}$ NAALC, available at http://www.naalc.org/.

${ }^{19}$ On the background to the negotiation of the NAALC, see Kate E. Andrias, "Gender, Work, and the NAFTA Labor Side Agreement," (2003) 37 San Francisco Law Review 521, 53043; Rainer Dombois, Erhard Hornberger \& Jens Winter, "Transnational Labor Regulation in the NAFTA - A Problem of Institutional Design? The Case of the North American Agreement on Labor Cooperation between the USA, Mexico and Canada," (2003) 19 International Journal of Comparative Labour Law and Industrial Relations 421, 425-28; John R. MacArthur, The Selling of "Free Trade": NAFTA, Washington, and the Subversion of American Democracy (New York: Hill and Wang, 2000). 
2. the right to bargain collectively

3. the right to strike

4. prohibition of forced labor

5. limitation of child labor

6. minimum wage, hours of work an other labor standards

7. elimination of employment discrimination

8. equal pay for women and men

9. occupational health and safety

10. workers' compensation

11. migrant worker protection

In addition to setting out principles, the accord requires each government to comply with and enforce its own labor laws. It establishes the Commission on Labor Cooperation, which is mandated to promote cooperative activities aimed at advancing the goals of the NAALC, but is not given enforcement powers. For this purpose, the NAALC requires each signatory to appoint a National Administrative Office (NAO) and provides that a complaint alleging that a country is failing to enforce its own laws can be filed with the NAO of another country. If the complaint is accepted, an investigation is conducted and if the NAO finds that the laws are not being enforced, it may request ministerial consultations. If the complaint is not resolved at this level, and does not involve freedom of association, the right to bargain or the right to strike, then it may be referred to an Evaluation Committee of Experts. Only complaints regarding occupational health and safety, child labor, or minimum wages laws can go before an arbitration panel vested with power to impose penalties for enforcement failures.

As many commentators have noted, while the NAALC expresses a commitment to a set basic labor rights, it does not actually require the parties to amend their own laws into order to implement them. Rather, it simply requires the parties to enforce the laws they have. In marked contrast to the trade-related provisions of NAFTA, which give investor rights priority over state sovereignty, the NAALC gives national sovereignty 
priority over labor rights. Each party retains the "right to establish its own domestic labor standards, and to adopt or modify accordingly it labor laws and regulations."20

These constitutive arrangements create the conditions for regulatory competition described in Model 1: at the economic level, increased capital and product mobility generate more intense competition which gives capital greater economic leverage over labor; at the institutional level, labor standards are set nationally or sub-nationally, depending on the constitutional arrangements of each of the signatories, but not at a transnational level that coincides with the boundaries of capital and product markets. Moreover, mechanisms to encourage each jurisdiction to enhance, protect, or even enforce workers' rights are weak.

It should be added that according to this model pressure would be greater on those states and jurisdictions with higher labor standards and most dependent on trade. A recent study created a quantitative index of labor standards in the United States and Canada. As most observers would have predicted, it found that overall Canada had higher labor standards than the United States. Of particular interest for our purposes is that the study rated Canada's collective bargaining laws as significantly stronger than those of the U.S. Indeed, the gap between the United States and Canada on this measure was among the largest identified by the study. ${ }^{21}$ Further, Canada is the most trade dependent of the OECD countries. Its exports as a percentage of gross national product

\footnotetext{
${ }^{20}$ NAALC, Article 2. Clyde Summers, "NAFTA's Labor Side Agreement and International Labor Standards,” (1999) 3 Journal of Small and Emerging Business Law 173; Emmanuelle Mazuyer, "Labor Regulation in the North American Free Trade Area: A Study of the North American Agreement on Labor Cooperation," (2001) 22 Comparative Labor Law \& Policy Journal 239, 245.

${ }^{21}$ Block, Labor Standards, 95 (the comparison year was 1998).
} 
in 1995 was 33.5 while that of the United States was 8. The OECD average was 23.1

percent. ${ }^{22}$ As a result, this model would predict that the pressure on Canadian collective bargaining law would be particularly sharp.

${ }^{22}$ Neil Fligstein, The Architecture of Markets (Princeton: Princeton University Press, $2001), 203$. 


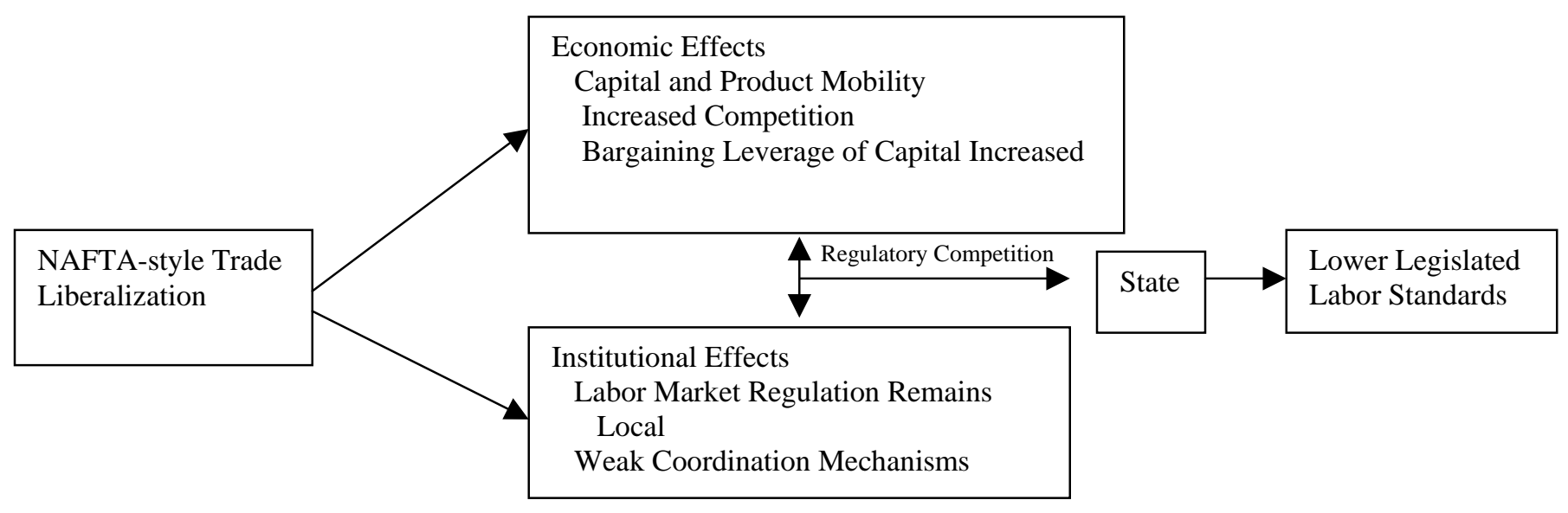

Figure 1

Model of the Race to the Bottom Theory

B. The RTB Model's Limitations

Recent literature examining the impact liberalized trading regimes on regulation, even in institutional contexts that foster regulatory competition, suggests that races to the bottom do not necessarily follow and that a variety of politico-economic processes contribute to regulatory outcomes. ${ }^{23}$ Some studies have illustrated this point through an examination of an analogous situation, labor market regulation in federal states. A brief comparison of the United States and Canada, two federal states with very different constitutional divisions of powers over labor and employment law, is suggestive.

In the United States, the courts held that the federal government's National Labor Relations $\mathrm{Act}^{24}$ substantially pre-empted state jurisdiction, thereby limiting the opportunity for regulatory competition between states to occur. This was partially

${ }^{23}$ For example, see the essays collected in Daniel C. Esty and Damien Geradin, eds., Regulatory Competition and Economic Integration (New York: Oxford UP, 2001).

${ }^{24}$ NLRB v. Jones \& Laughlin Steel Co., 301 U.S. 1 (1937); National Labor Relations (Wagner) Act of 1935, ch. 372, 49 Stat. 449. 
undone by the Taft-Hartley Act, ${ }^{25}$ which permitted states to enact "right-to-work" laws that weakened union security. A number of states exercised this power, particularly in the southern US. That change, in conjunction with fierce employer resistance to unionization, racism and disunity in low union densities in southern states. ${ }^{26}$

Although the spread of right to work laws slowed in the 1960s, their significance grew as employers became more aggressive in pursuing non-union production strategies. One way to achieve that result was to shift investment to greenfield sites, often located in right-to-work states. These trends intensified in the 1980s, when northern and midwestern states lost 1.5 million manufacturing jobs and $\$ 40$ billion in pay, largely to rightto-work states. ${ }^{27}$ Internal regulatory competition, however, cannot be invoked as the principal reason for the weakness of U.S. labor law. Barenberg emphasizes other factors, including decentralized competition, ineffective coordination mechanisms, and the role of local state law. Decentralized competition occurred because of the extremely fragmented bargaining structure that was institutionalized under the NLRA and because employers were free to divest from unionized plants and reinvest in non-union ones. Coordinating mechanisms that might have overcome this fragmentation (such as peak union and employer associations, national political parties, etc) were too weak to play this role. Finally, local elites, particularly in the south, were able to mobilize state and local power

${ }^{25}$ Labor-Management Relations (Taft Hartley) Act, ch. 120, 61 Stat. 136 (1947).

${ }^{26}$ Michael Honey, Southern Labor and Black Civil Rights (Urbana, IL: University of Illinois Press, 1993).

27 Thomas A. Kochan, Harry C. Katz, and Robert B. McKersie, The Transformation of American Industrial Relations (Ithaca: ILR Press, 1994); Rick Fantasia and Kim Voss, Hard Work (Berkeley: University of California Press, 2004), 74-75. 
to defeat the exercise of federally guaranteed core labor rights. ${ }^{28}$ The result was a centralized but ineffective legal regime.

Canada presents an interesting comparison. As mentioned, courts have held that federal jurisdiction over labor and employment is very limited, leaving regulatory authority vested in the provinces. This constitutional arrangement favors regulatory competition, since capital is fairly free to move between provinces. Yet, there has not been a race to the bottom. For example, within a few years after the federal government's industrial relations legislation was struck down in1925, nearly all the provinces passed laws either opting into it or creating parallel mechanisms of their own. During World War II the federal government's powers expanded under emergency legislation and it introduced U.S. style collective bargaining law to Canada. However, after the war's end and the resumption by the provinces of their normal authority, with a few years, all provinces adopted a version of that scheme. ${ }^{29}$ Perhaps for this reason, the effect of federalism on the development of Canadian labor law has not received much scholarly attention. In his book Reconcilable Differences Paul Weiler briefly argues that the provinces have served as "laboratories for legal experimentation" that generally led to

\footnotetext{
${ }^{28}$ Mark Barenberg, "Labor Federalism in the United States: Lessons for Coordinated Decentralization in Supranational Regimes," in Esty and Gerdin, Regulatory Competition and Economic Integration. Also see Bruce Elmslie and William Milberg, "Free Trade and Social Dumping: Lessons from the Regulation of Interstate Commerce," (May-June 1996) Challenge 46 (arguing that the federal Fair Labor Standards Act eliminated socially destructive regulatory competition over child labor laws) and Lane Kenworthy, "Economic Integration and Convergence: A Look at the U.S. States," (1999) 80 Social Science Quarterly 858 (arguing economic integration and regulatory competition has not led to harmonization, citing the limited spread of right-to-work laws as one example).

${ }^{29}$ Judy Fudge and Eric Tucker, Labour Before the Law (Toronto: Oxford, 2001).
} 
positive innovation. The reason for this, he suggests, was that in large provinces, like Ontario, Quebec and British Columbia, plant location decisions are largely driven by other factors such as the availability of raw materials, transportation costs, access to markets, etc, and that variation in labor law pales by comparison. ${ }^{30}$ To my knowledge, no one has argued that regulatory competition has exerted a significant downward influence on labor law and employment standards in Canada. ${ }^{31}$

The simple lesson to be learned from this brief comparison is that a regime that creates the structural conditions for regulatory competition may still have strong labor laws, while a more centralized regime may not. The structural scope for regulatory competition within federal states is only one factor that determines the trajectory of labor law. The same lesson has been applied to international and regional free trade arrangements. Indeed, as noted earlier, there seems to be an emerging consensus that the structural possibilities for regulatory competition opened up by NAFTA and similar kinds of trade agreements have not produced races to the bottom in the area of labor law.

C. Moving the Debate Forward: Towards a Reconstructed Model of Trade Liberalization's Effect on Labor Market Regulation

${ }^{30}$ Paul Weiler, Reconcilable Differences (Toronto: Carswell, 1980), 11.

${ }^{31}$ F.R. Scott, Essays on the Constitution (Toronto: University of Toronto Press, 1977), ch. 25, argued that divided jurisdiction over labor relations was undesirable because it interfered with the ability of unions to bargain collectively with employers who operated nationally. He did not argue that provincial jurisdiction was promoting a regulatory race to the bottom in labor standards. 
The critics of the RTB model presented in Figure 1 make a strong case that it oversimplifies the effect of NAFTA-style trade liberalization on labor law. In this part of the paper I respond to that criticism in two ways. On the one hand, I argue that their assessment of NAFTA's impact is based on an artificially narrow focus on private sector labor legislation. Not only does this leave out public sector collective bargaining law but, more importantly, it fails to consider NAFTA's impact on the effectiveness of the collective bargaining regime. This results in an understatement of the NAFTA effect.

On the other hand, I accept that a more nuanced, less structural model is needed that other factors need to be brought in to explain regulatory outcomes. I identify and build into a revised model some mediating contextual factors that allow a greater role for agency and contingency.

\section{From Private Sector Labor Legislation to the Effectiveness of Labor Market}

\section{Regulation}

The argument that NAFTA has not promoted a RTB is based on an examination of private sector labor legislation. Its use as a measure is appealing if only because legislative changes are relatively easy to track and assess. This focus, however, misses what are arguably some of NAFTA's more important effects.

First, it ignores developments in public sector collective bargaining, presumably on the assumption, unstated in the literature, that changes in that area are unrelated to globalization. That assumption, however, is problematic. A number of commentators have pointed to links between globalization and government fiscal and tax policies, reductions in government services, and privatization, all major causes of the harsher 
public-sector collective bargaining climate that has led to legislative retrenchment. ${ }^{32}$

Belman et al expressly spell out these links.

With greater global competition and reduced tariff barriers it is easier for capital to flow into countries with low taxes and few regulations and to export into high-cost countries. Governments are under increased pressure to compete for business investment and the associated jobs, and this interjurisdictional competition may occur in the form of tax reductions and reduced regulations. The tax reductions directly affect the public sector budget constraints and employment relations, especially given the importance of labor cost in the provision of many public services. Reduced regulation indirectly reduces the demand for government services, since such regulation was often provide through the public sector. $^{33}$

It is also important to emphasize that in both Canada and the United States, collective bargaining is becoming a mechanism that is primarily used to establish terms and conditions of employment in the public sector. Union density in the private sector in Canada has dropped below twenty percent, while public sector union density is above seventy-five percent. In the United States, private sector unionism has dropped below

${ }^{32}$ Joseph B. Rose, Gary N. Chaison and Enrique de la Garza, “A Comparative Analysis of Public Sector Restructuring in the U.S., Canada, Mexico, and the Caribbean,” (2000) 21 Journal of Labor Studies 601 (increased global competition, trade liberalization, and deregulation exerting tremendous pressure on public sector); Gene Swimmer, "Public-Sector Labour Relations in an Era of Restraint and Restructuring: An Overview," in Gene Swimmer, ed., .Public-Sector Labour Relations in an Era of Restraint and Restructuring (Toronto: Oxford University Press, 2001), 1, 8 (governments in a globalized economy fear tax increases and regulation will lead to be unattractive to capital).

33 Dale Belman, Morley Gunderson and Douglas Hyatt, "Public Sector Employment Relations in Transition," in Dale Belman et al., eds., Public Sector Employment in a Time of Transition (Madison: Industrial Relations Research Association , 1996), 4-5. 
nine percent, while public sector unionism is at thirty-seven percent. ${ }^{34}$ Hence an exclusive focus on private sector collective bargaining law yields a very distorted picture of the world of collective bargaining.

Moreover, by focusing narrowly on legislation, researchers fail to consider what is arguably a more important outcome, the impact of trade liberalization on the effectiveness of labor market regulation. The reasons why we ought to be concerned with regulatory effectiveness are fairly obvious. Decades of law and society scholarship have emphasized that there is often a huge gap between law on the books and the law in action. While law on the books may have a certain expressive or symbolic value, if it fails instrumentally to achieve its objectives then there has been regulatory failure and the putative beneficiaries of the law are deprived of it promise. In short, we would get a very distorted view of reality if we were to rely solely on legislative change as a measure of the impact of trade liberalization on labor law. ${ }^{35}$ For these reasons the focus of a reconstructed model is on the effectiveness of labor market regulation

Changes in the effectiveness of labor market regulation can come about in a number of ways. First, labor legislation may be intentionally changed to reduce its

${ }^{34}$ Andrew Jackson and Sylvain Schetagne, Solidarity Forever? An Analysis of Changes in Union Density (Ottawa: Canadian Labour Congress, Research Paper \#25, July 2003), 14. For the USA, see tables online at www.unionstats.com.

${ }^{35}$ David Weil, "Implementing Employment Regulation: Insights on the Determinants of Regulatory Performance," in Bruce E. Kaufman, ed., Government Regulation of the Employment Relation (Madison: Industrial Relations Research Association Series, 1997), 429; Stephanie Bernstein et al., "Precarious Employment and Law's Flaw's: Identifying Regulatory Failure and Securing Effective Protection for Workers," forthcoming in Leah Vosko, ed., Precarious Employment: Understanding Labour Market Insecurity in Canada (Montreal and Kingston: McGill-Queen's University Press, 2005). 
effectiveness. This can be thought of as direct deregulation of labor markets and is a policy goal that is frequently advocated by those who believe existing levels or forms of state regulation are harmful to the economy. ${ }^{36}$ There may also be cases where legislative change has the unintended effect of making labor market regulation less effective.

A second way that labor law can become less effective in through legislative inaction in the context of a rapidly changing labor market. This constitutes what has been characterized as passive deregulation. ${ }^{37}$ An obvious example is that the value of certain labor standards, like the minimum wage, erodes over time due to inflation. Inaction renders the scheme of regulation less effective in achieving its goal of protecting workers against socially unacceptable levels of low pay. Another example is the development of structural mismatches between static schemes of labor market regulation and changes in the labor markets to which they apply. This is particularly salient in the context of trade liberalization, which has promoted employers to pursue a variety of flexibilization strategies. For example, much has been written about the growth of contingent or precarious employment and the problems it creates for current modes of labor regulation that were constructed on the platform of the standard employment relation. ${ }^{38}$ Yet, little

${ }^{36}$ For example, in Canada the Fraser Institute regularly advances this position. For example, see its publication, Measuring Labour Markets in Canada and the United States: 2004 Edition, Online at http://www.fraserinstitute.ca/shared/readmore.asp?sNav=pb\&id=690, 24-28.

${ }^{37}$ Kerry Rittich, Vulnerability at Work: Legal and Policy Issues in the New Economy (Ottawa: Report to the Law Commission of Canada, 2004), 24-30.

38 On the growth of 'non' standard employment and the resulting labor regulation difficulties, see "Special Issue on Changing Contours of Employment and New Modes of Labour Regulation," (2004) 42 British Journal of Industrial Relations 593; Leah Vosko, ed., Precarious Employment: Understanding Labour Market Insecurity in Canada (Montreal and Kingston: McGill-Queen's University Press, forthcoming 2005); Katherine V. W. Stone, From Widgets to 
has been done to revamp labor law to meet this challenge. Similarly, a central premise of Canadian and U.S. labor law is that collective bargaining should occur at the enterprise level. This arrangement has always presented a challenge for unions, especially outside oligopolistic sectors of the economy where employers resisted joint regulation with unions to take wages out of competition. Trade liberalization has exacerbated the coordination problem and, as result, pattern bargaining has broken down and there is greater wage competition within the unionized workforce. ${ }^{39}$ Again, in these circumstances it is arguable that legislative inaction reduces the effectiveness of labor market regulation - a form of passive deregulation.

A third way of altering the effectiveness of existing labor law is by administrative means. Changes in the way the administrative bodies interpret and enforce the law can significantly alter its effectiveness. These administrative changes are much less visible than legislation, and sometime will be referred to as disguised or hidden deregulation. Their effects, however, can be just as great as those made directly by legislation. For example, a change in the interpretation of the meaning of the term "employee" could Digits (Cambridge: Cambridge U.P., 2004); Judy Fudge and Leah Vosko, "Gender, Segmentation and the Standard Employment Relationship in Canadian Labour Law," (2001) 22 Economic and Industrial Democracy 271.

${ }^{39}$ On the issue of decentralized bargaining, see Harry C. Katz, "The Decentralization of Collective Bargaining: A Literature Review and Comparative Analysis,” (1992) 47 Industrial and Labor Relations Review 3; Anne Forrest, "Bargaining Units and Bargaining Power," (1986) 41 Relations Industrielles 840; Judy Fudge, "The Gendered Dimension of Labour Law: Why Women Need Inclusive Unionism and Broader-based Bargaining," in Linda Briskin and Pat McDermott, eds., Women Challenging Unions: Feminism, Democracy, and Militancy (Toronto: University of Toronto Press, 1993), 231. On the problem of fragmentation under globalization, see Joseph B. Rose and Gary N. Chaison, "Unionism in Canada and the United States in the $21^{\text {st }}$ Century," (2001) 56 Relations Industrielles 34, 44-49. 
significantly alter the scope of the law's application. ${ }^{40}$ Of course, the extent of administrative authority or discretion may vary significantly from scheme to scheme, but often there is usually a fair bit of leeway. To the extent that courts play a role in supervising an administrative body's interpretation of law or exercise of discretion, they too become implicated in the administration of the law and the effect of their interventions on regulatory effectiveness must also be considered.

Administrative deregulation can also occur through the enforcement process. ${ }^{41} \mathrm{~A}$ reduction in the resources available for enforcement or a change in the enforcement strategy can greatly alter the regime's effectiveness and its impact on labor costs. For example, strong occupational health and safety laws can be rendered ineffective without weakening employers' substantive duties by a reduction in the enforcement budget or by a decision to rely exclusively on persuasive strategies even after they have failed to alter an employers' behavior. ${ }^{42}$ NAALC's focus on the enforcement of existing labor laws treats this method of hidden deregulation is "illegitimate."

Finally, changes in the labor market that deter employees from exercising or asserting their legal rights also impair the regime's effectiveness. Fear of retaliation or concern that an employer will simply close up shop if forced to comply with the law is a

${ }^{40}$ Judy Fudge, Eric Tucker, and Leah Vosko, The Legal Concept of Employment: Marginalizing Workers (Ottawa: Report for the Law Commission of Canada, 2002); Marc Linder, The Employment Relation in Anglo-American Law: A Historical Perspective (New York: Greenwood Press, 1989).

${ }^{41}$ Bob Hepple, "Enforcement: The Law and Politics of Cooperation and Compliance," in Bob Hepple, ed., Social and Labour Rights in a Global Context (Cambridge: Cambridge University Pres, 2002), 238.

${ }^{42}$ Neil Gunningham and Richard Johnstone, Regulating Workplace Safety: Systems and Sanctions (Oxford: Oxford University Press, 1999). 
powerful disincentive for employees, whether they are contemplating joining a union, complaining about illegally low wages, or calling a health and safety inspector. ${ }^{43}$

A switch in focus from legislation to regulatory effectiveness creates significant methodological problems, since it is much more difficult to identify and estimate changes in effectiveness. There is a rich literature on the effects of globalization on labor markets, ${ }^{44}$ which is largely unconnected to the literature addressing labor market regulation. While the two questions should not be collapsed into one, an assessment of regulatory effectiveness will necessarily have to consider labor market changes, both for the purpose of discussing mismatches between regulatory arrangements and labor market realities and for data that is indicative of regulatory failure.

\section{Bringing in Contextual Factors}

In modeling the impact of NAFTA on labor regulation, it is useful to identify two levels of determination: the structural and the politico-economic. I have already argued that NAFTA is intended to establish a conditioning framework within which capital, labor and government operate. In that way, it operates at the structural level of

${ }^{43}$ For example, see Richard Kazis and Richard L. Grossman, Fear at Work: Job Blackmail, Labor, and the Environment (Philadelphia: New Society Publishers, 1992).

${ }^{44}$ For a small sampling of the literature on labor market effects, see Lori Kletzer, Imports, Exports, and Jobs: What Does Trade Mean for Employment and Job Loss? (Kalamazoo: W.E. Upjohn Institute for Employment Research, 2002); Robert Scott, The High Cost of 'Free' Trade (Washington D.C.: Economic Policy Institute, Briefing Paper, November 2003); Lessons from NAFTA: The High Cost of Free Trade (Ottawa: Canadian Centre for Policy Alternatives, 2003; Bruce Campbell et al, Pulling Apart: The Deterioration of Employment and Income in North America Under Free Trade (Ottawa: Canadian Centre for Policy Alternatives, 1999); Noel Gaston and Daniel Trefler, "The Labour Market Consequences of the Canada-U.S. Free Trade Agreement," (1997) 30 Canadian Journal of Economics 18. 
determination and Model 1 captures its key elements. But, even after a set of constitutive decisions has been made, there are many mediating factors that will influence regulatory outcomes. For example, Gunderson hypothesizes that for trade liberalization to promote downward harmonization four linkages must exist: 1) the laws in question must be enforced; 2) the laws must lead to an actual or perceived increase in labor costs to employers; 3) higher labor costs deter investment and influence plant location; and 4) jurisdictions must compete for investment on the basis of reducing costly labor laws. ${ }^{45}$ This is a useful beginning, but I propose to elaborate a more general model that identifies three sets of mediating variables involving: economic complexity; internal adaptation in the collective bargaining scheme; and the external political, legal, ideological, and social environment that shapes government policy. ${ }^{46}$

There are three disputes in the economics literature that potentially complicate the relationship between trade liberalization and labor law. The first is a dispute over the magnitude of the changes in world trade that are associated with globalization and trade liberalization. For example, Fligstein shows that as a percentage of world GDP, world trade grew steadily from 1953 until it peaked in 1981, but that over the next sixteen years it fluctuated. He concludes that, viewed over the longer term, world trade is not

\footnotetext{
${ }^{45}$ Morely Gunderson, "Harmonization of Labour Policies under Trade Liberalization." (1998) 53 Relations Industrielles 24.

46 Fligstein, Architecture of Markets, 195 also argues that globalization theorists of both the left and right "want economic forces to be structural, inevitable, and everywhere dominating action." Instead, he offers a political-cultural approach that emphasizes the role of social and political forces.
} 
overwhelming national economies. ${ }^{47}$ It is, however, undoubtedly the case that since the beginning of the free-trade era, there has been a phenomenal growth in trade between the U.S. and Canada, more than doubling between 1985 and 2002. ${ }^{48}$

A second dispute is over the relative significance of labor costs in investment decisions. It has been argued that that even under conditions of competition, location decisions are driven by a variety of considerations, and that while local labor costs and the strength of local labor market regulation are factors, they are not necessarily the most important ones. Indeed, some studies suggest that labor standards play a relatively minor role in location decisions compared to factors such as the availability of natural resources, transportation costs, tax considerations, and market size. ${ }^{49}$ Other studies, however, show that higher wage costs are associated with lower employment growth in labor-intensive industries. $^{50}$

${ }^{47}$ Fligstein, Architecture of Markets, 196-97. Also see, Linda Weiss, The Myth of the Powerless State (Ithaca: Cornell University Press, 1999), 167-76.

48 John W. Foster and John Dillon, "NAFTA in Canada: The Era of a SupraConstitution," in Hemispheric Social Alliance, Lessons from NAFTA: The High Cost of Free Trade (2003), 47, Online at http://www.art-us.org/docs/high\%20cost\%20of\%20free\%20trade.pdf

${ }^{49}$ Kimberly Ann Elliot, Labor Standards, Development and CAFTA (Washington DC: Institute for International Economics, International Economics Policy Briefs, Number PB04-2, March 2004); Mario F. Bognanno et al, "The Influence of Wages and Industrial Relations Environments on the Production Location Decisions of U.S. Multinational Corporations," (2005) 58 Industrial and Labor Relations Review 171.

${ }^{50}$ James Heintz, Global Labor Standards: their impact and implementation (Amherst MA: Political Economy Research Institute, 2002). Also see Banks, "Globalization and Labour Standards" (arguing that competition on the basis of low labor costs and standards is much more likely in underdeveloped nations). 
A third dispute is over the optimality of a low-wage, low-standards economic strategy. It has been argued that lower labor standards may not be as advantageous as RTB supporters assume. For example, Kucera's study concludes that lower labor standards do not improve competitiveness and that, to the contrary, higher labor standards may be associated with other characteristics that make a jurisdiction attractive for investors. ${ }^{51}$ Other studies have reached similar conclusions and argue that there is no empirical evidence to demonstrate that the low-wage, weak labor protection model of economic growth is optimal. ${ }^{52}$

No attempt will be made in this paper to sort out these disputes. Rather, the point is simply that NAFTA's economic effects are not as straightforward as the RTB model assumes. Thus, while labor standards are part of the mix of considerations in the calculus of location decisions, their salience is likely to depend on a number of factors that include not only the macro-economic factors identified above, but also the degree of interjurisdictional disparity in standards, and industry or even employer specific production regimes. As well, it is likely that some labor standards are more related to competitiveness than others. For example, it seems plausible to assume that strong antidiscrimination laws are less likely to create or to be seen to create competitive disadvantage than laws that strictly regulate hours of work.

${ }^{51}$ David Kucera, The Effects of Core Labor Rights on Labor Costs and Foreign Direct Investment: Evaluating the "Covnentional Wisdom (Geneva: International Institute for Labour Studies, Decent Work Research Programme, DP/130/2001). Also, see Drusilla K. Brown, International Trade and Core Labour Standards: A Survey of Recent Literature (Paris: OECD, Labour Market and Social Policy, Occasional Papers, No. 43, 2000).

${ }^{52}$ See studies discussed in Fligstein, Architecture of Markets, 213-20. 
To the extent that NAFTA's economic effects are more moderate than RTB theorists assert, the degree of economic compulsion driving a race to the bottom is reduced, leaving more room for states, firms, and unions to make strategic choices. This, in turn, marginally lessens the pressure on collective bargaining regimes and opens up spaces for political, legal, and civil society influences to operate.

A second point at which mediating factors operate is within the existing labor and employment law regime, particularly through the mechanism of internal adaptation. Here it is assumed that trade liberalization and regulatory competition generate pressure on employers to increase output per unit of labor input, but that this pressure may be addressed within the existing regulatory framework. To the extent that adjustment takes place within the existing framework, labor market deregulation will be a lower priority for employers. ${ }^{53}$

Internal adaptation can occur on at least two levels. At the macro-level, collective bargaining laws contained within themselves competing policy goals and visions. For some, the goal of collective bargaining laws was to advance a vision of industrial democracy in which workers and organized workers would jointly determine the rules that would govern their joint endeavor. This vision assumed that collective bargaining would continue within a capitalist economy, but it allowed for greater democracy on the assumption that either such arrangements would increase productivity or that competitive pressures would be alleviated by virtue of the spread of collective bargaining across

53 Passive and hidden deregulation has been discussed earlier as ways of reducing the effectiveness of labor market regulation, and they might also be considered as mechanisms of internal adaptation. However, it is preferable to treat them as changes to the regime itself rather than as internal adaptations. 
industry. For others, collective bargaining was simply an alternative mechanism for negotiating terms and conditions of employment that employees might opt into, unconnected to any broader vision of how relations of production might be made more consistent with democratic norms. The crucial point here is not which vision is preferable, but that the same statutory regime could function either as a promoter of industrial democracy or as an unadorned market mechanism depending on how it was interpreted and, more importantly, on the institutional, ideological, and politicaleconomic environment in which it operates. To the extent that the more transformative ambitions of collective bargaining are reined in, it is hypothesized that employers in a NAFTA-style free-trade environment will find it less threatening. ${ }^{54}$

A second or micro-level of internal adaptation is built into framework laws, like labor relations acts, that establish a baseline of rights and a set of procedures through which the specific parties establish and negotiate the substantive terms of their relationship. Such a scheme is inherently adaptive insofar as it gives each party ample leeway to pursue its agenda, leaving the outcome to the exercise of bargaining power in the context of the market. This internal adjustment could take two forms. In the optimistic view, which mirrors the industrial democracy perspective although now is less explicitly linked to that agenda, unions and employers can take the high road on which they negotiate win-win arrangements that create stronger firms more able to compete in the global market, while providing workers with higher pay, more involvement and greater job security. In this view, competitiveness can be pursued cooperatively and progressively. The alternative is the low road, where management uses its leverage in the

${ }^{54}$ Harry J. Glasbeek, "Labour Relations Policy and Law as a Mechanism of Adjustment," (1987) 25 Osgoode Hall Law Journal 179. 
collective bargaining process to extract concessions and intensify work. In either event, adjustment occurs, although winners and losers change. ${ }^{55}$

Finally, the third set of mediating factors operates externally to the labor and employment law regime potentially as constraints on the structural pressures generated by trade liberalization. These constraints can operate through the political system, the legal system, and civil society, and on different spatial (eg. national, international) levels. Beginning with the political, it has been argued that nation states are still a crucial site of resistance to globalization since social power is still rooted nationally. Indeed, it is through the exercise of sovereign national power that liberalized trading regimes are constructed. Thus, while these regimes may be designed with the aim of disciplining the democratic political process, it is arguably still possible for workers and others who are adversely affected to mobilize nationally and successfully constrain the neo-liberal project, through institutionalized channels, such as participation in elections and formal lobbying. ${ }^{56}$ Indeed, there is a large literature emphasizing that states have responded to the pressures of globalization in a variety of ways, reflecting the historical institutionalization of class and of state-market relations, often distinguishing between liberal market economies (LMEs) and coordinated market economies (CMEs). ${ }^{57}$

\footnotetext{
${ }^{55}$ For a brief review, see Anil Verma and Richard P. Chaykowski, "Employment and Employment Relations at the Crossroads," in Anil Verma and Richard P. Chaykowski, eds., Contract and Commitment: Employment Relations in the New Economy (Kingston, ON: IRC Press, Industrial Relations Centre, Queen's University, 1999), 1, 10-14.

56 Leo Panitch, "Globalization, States, and Left Strategies," (1996) 23 Social Justice79; Jeffrey Ayres, "Power Relations under NAFTA: Reassessing the Efficacy of Contentious Transnationalism," (2004) 74 Studies in Political Economy 101.

57 eg. Peter Hall and David Soskice, eds., Varieties of Capitalism: The Institutional Foundations of Comparative Advantage (New York: Oxford University Press, 2001); Geoffrey
} 
Arguably, then, the race to the bottom could be thwarted or slowed because national or sub-national political resistance to the erosion of labor standards has been sufficient to counter the downward pressure.

Political action is not just confined to the national sphere and, indeed, the processes of globalization and trade liberalization have challenged social movements and labor organizations to develop transnational political and organizing strategies. Jeffrey Ayres has recently examined the development of what he calls "contentious transnationalism" and finds there has been an increase in institutionalized political activity facilitated by the NAALC complaints procedure and in non-institutionalized activity such as cross-border campaigns focused on government action particularly in the US-Mexico border region. ${ }^{58}$ We will consider its effects in the context of international legal and civil society constraints.

When we turn to legal restraints our focus is in on instruments that formally limit the power of governments to reduce labor standards. At the national level, the clearest instance would be constitutional protections of labor rights, such as freedom of

Garrett, Partisan Politics in the Global Economy (Cambridge: Cambridge University Press, 1998) (social democratic corporatism has successfully responded to the pressures of globalization and offers a viable alternative); Evelyne Huber and John D. Stephens, Development and Crisis of the Welfare State (Chicago: University of Chicago Press, 2001); Weiss, Myth of the Powerless State (globalization is firming up varieties of capitalism);

${ }^{58}$ Ayres, "Power Relations," supra.; David M. Trubek et al., "Transnationalism in the Regulation of Labor Relations: International Regimes and Transnational Advocacy Networks," (2000) 25 Law and Social Inquiry 1187 (elements of a network are emerging but not fully effective system in place). Also see James Atleson, “The Voyage of the Neptune Jade: Transnational Labour Solidarity and the Obstacles of Domestic Law," in Labour Law in an Era of Globalization, 379 (on the role of domestic law in limiting the scope for transnational labor solidarity). 
association or guarantees of equality rights. The strength of this kind of constraint will obviously vary from state to state and some labor rights will be better protected than others. We will return to examine the respective constitutional rights of workers in Canada and the United States in our case study.

At the international or transnational level, there is a wide range of instruments that potentially limit state action. The International Labour Organization (ILO) has historically been the most important body engaged in the construction of an international labor rights regime through its declarations, conventions, and, most recently, its adoption in 1998 of the Declaration on Fundamental Principles and Rights at Work. There is a large literature assessing the ILO's effectiveness but for our purposes here it is sufficient to note that the ILO's enforcement capacity is quite limited. ${ }^{59}$ Nevertheless, the norms generated by the ILO may influence domestic legal decision-making or may support society constraints. Another potential source of international restraints is through the inclusion of labor protections in multilateral or bilateral trade agreements. The issue of protecting labor standards through the WTO has been much debated, but no action has been taken, so this is a mere hypothetical. ${ }^{60}$ Labor standards are addressed in the

${ }^{59}$ For a small sample of the literature, see Philip Alston, "'Core Labour Standards' and the Transformation of the Labour Rights Regime," (2004) 15 European Journal of International Law 457; Sean Cooney, "Testing Times for the ILO: Institutional Reform for the New International Political Economy," (1999) 20 Comparative Labor law and Policy Journal 365; Virginia Leary, “The Paradox of Workers' Rights as Human Rights," in Compa and Diamond, Human Rights, Labor Rights, and International Trade, 22; Leah Vosko, “'Decent Work': The Shifting Role of the ILO and the Struggle for Global Social Justice,” (2002) 2 Global Social Policy 19.

${ }^{60}$ eg. Clyde Summers, “The Battle in Seattle: Free Trade, Labor Rights, and Societal Values," (2001) 22 University of Pennsylvania Journal of International Economic Law 61; Robert 
NAALC, but as noted it only requires states to enforce their laws, not to establish or maintain a minimum set of labor standards. Nevertheless, the NAALC does support in principle high labor standards and promotes them through the Commission for Labor Cooperation. Thus, as in the case of the ILO, it is arguable that notwithstanding the weakness of the mechanisms for implementation, the NAALC may influence decisionmaking by domestic courts and tribunals or, more generally, promote an ideological climate that exerts a countervailing force to the pressures for lower labor standards. ${ }^{61}$ Again, the question of the strength of these effects is an empirical one and will be examined in the context of the case study.

Finally, there may be ideological or civil society restraints on the erosion of labor standards. The idea here is that if certain norms become sufficiently widespread governments and transnational corporations will be constrained in efforts to pursue competitiveness-enhancing and profit-maximizing strategies. Thus, for example, Langille argues that the view that economic growth should be pursued independently of social justice and human rights is increasing being challenged by Sen and others who

Howse, "The World Trade Organization and the Protection of Workers' Rights," (1999) 3 Journal of Small \& Emerging Business Law 131; Daniel S. Ehrenberg, "From Intention to Action: An ILO-GATT/WTO Enforcement Regime for International Labor Rights," in Lance A. Compa and Stephen F. Diamond, eds., Human Rights, Labor Rights, and International Trade (Philadelphia: University of Pennsylvania Press, 1996), 163-180.

${ }^{61}$ Kate E. Andrias, "Gender, Work, and the NAFTA Labor Side Agreement," (2003) 37 San Francisco Law Review 521 (expressive function of NAALC); Emmanuelle Mazuyer, "Labor Regulation in the North American Free Trade Area: A Study of the North American Agreement on Labor Cooperation,” (2001) 22 Comparative Labor \& Policy Journal 239 (some indirect effects). 
argue that the promotion of human development should guide public policy. ${ }^{62}$ As this view gains popular support, governments will face greater political opposition to labor market deregulation, particularly when it adversely affects the most vulnerable workers.

As well, the spread of a counter-hegemonic ideology may also promote the growth of strong civil society groups whose activities constrain the behavior of transnational corporations and governments. ${ }^{63}$ Campaigns by NGOs and workers' rights advocacy groups to pressure transnational corporations into adopting codes of conduct governing work conditions of suppliers are the most prominent manifestation of this influence. ${ }^{64}$ Another example is the campaign recently initiated by a consortium of AFLCIO unions to pressure Walmart into raising wages and improving conditions, not by

${ }^{62}$ Brian A. Langille, "Seeking Post-Seattle Clarity - and Inspiration," in Joanne Conaghan et al., eds., Labour Law in an Era of Globalization (Oxford: Oxford University Press, 2002), 137; Amartya Sen, Development as Freedom (New York: Alfred A. Knopf, 1999); Joseph Stiglitz, "Employment, Social Justice and Societal Well-Being," (2002) 141 International Labour Review 9.

${ }^{63}$ Kimberly Ann Elliot and Richard B. Freeman, Can Labor Standards Improve Under Globalization? (Washington, D.C.: Institute for International Economics, 2003), ch. 3 (referring to such activists as human rights vigilantes). Also see Ruben J. Garcia, "Transnationalism as a Social Movement Strategy: Institutions, Actors and International Labor Standards,” (2003) 10 University of California Davis Journal of International Law \& Policy 1.

${ }^{64}$ The literature on corporate codes is voluminous. For a small sample, see Adelle Blackett, "Global Governance, Legal Pluralism and the Decentered State: A Labor Law Critique of Codes of Corporate Conduct,” (2001) 8 Indiana Journal of Global Legal Studies 401; Harry Arthurs, "Private Ordering and Workers' Rights in the Global Economy: Corporate Codes of Conduct as a Regime of Labour Market Regulation," in Labour Law in an Era of Globalization, 471. 
organizing its employees, but by mobilizing public opinion. ${ }^{65}$ Again, the question of the extent and direction of an ideological shift, and the effectiveness of civil society campaigns is an empirical one; here we are only concerned to identify factors that may counteract pressures to reduce labor standards arising from regulatory competition in a liberalized trading regime.

Thus to conclude, a more nuanced model of the effects of NAFTA-style trade liberalization on labor standards must take into account a wide-range of variables. Figure 2 depicts such a model, incorporating the variables discussed above.

${ }^{65}$ Steven Greenhouse, "Unions to Push for Better Pay at Walmart," New York Times, 11 December 2004, A-16. 


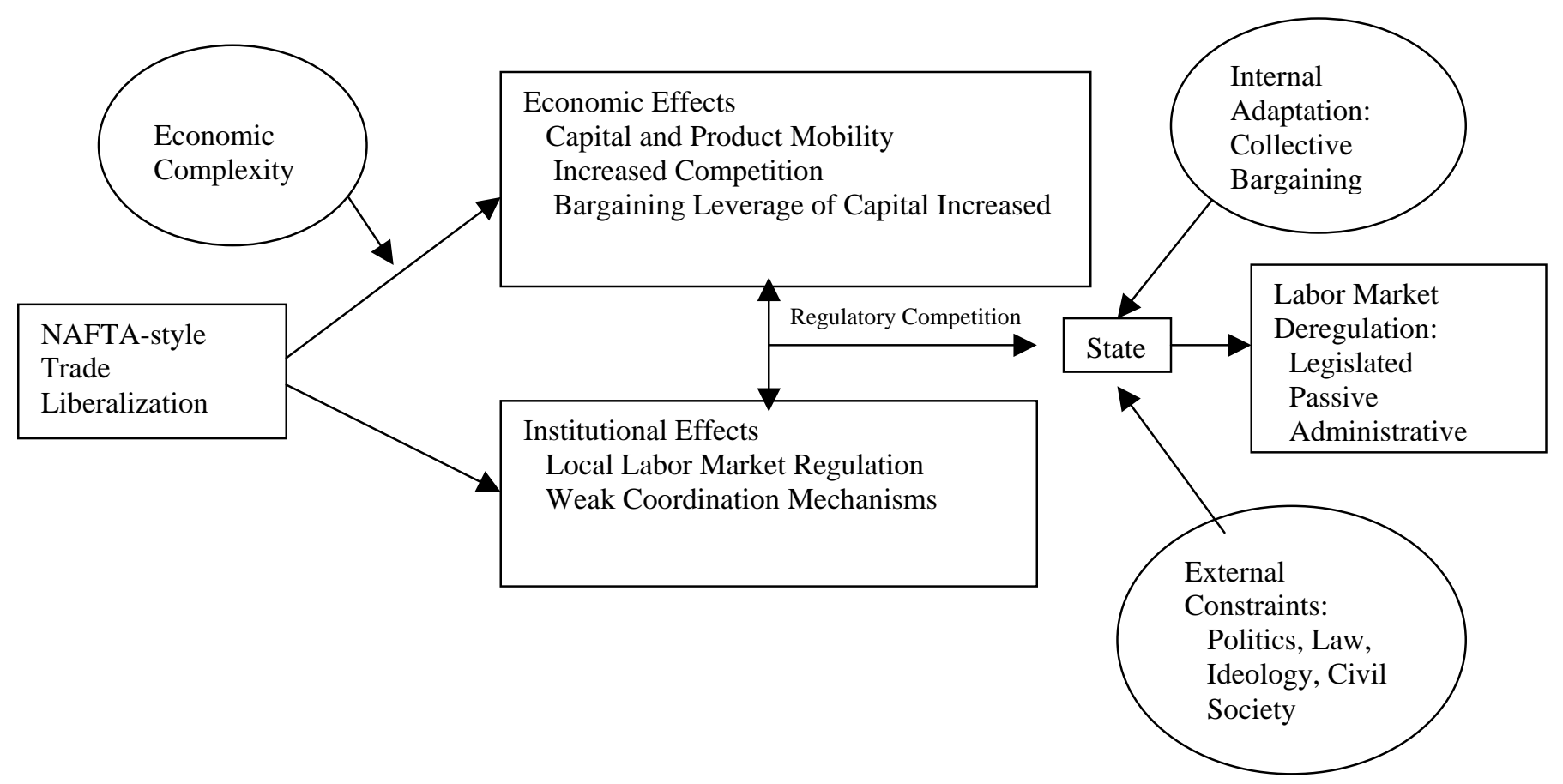

Figure 2

Nuanced Model of the Impact of Trade Liberalization on

Labor Standards

III. Case Study: Collective Bargaining Law in Canada and the U.S.

Collective bargaining laws historically have been shaped by histories of struggle between workers acting collectively to improve the terms and conditions of their employment and to provide them with a means of participating in decision-making that affects them as individuals and as a group, and employers seeking to contain labor costs, limit intrusions on managerial prerogative and constrain industrial action. The government becomes involved not as the neutral umpire, but with the goal of advancing what it views to be the public interest at any given time. This may involve a variety of goals such as promoting industrial democracy and the values associated with it, maintaining the balance between production and domestic consumption, containing the spillover effects of industrial conflict, supporting export-led growth, etc. As a result, 
labor law is likely to be sensitive to changes in the balance of power between labor and capital and shifts in state policy. ${ }^{66}$

According to our nuanced model, NAFTA-style trade liberalization is liable to generate some degree of structural pressure on states to weaken labor market regulation through direct legislation action, passivity in the face of changing labor markets, and administrative changes. The actual impact of trade liberalization, however, will depend on the kinds of mediating factors discussed above. The following case studies of Canada and the U.S. each begin with an assessment of the trajectory of collective bargaining law. This is followed by an examination of two of the three mediating factors, internal adaptation and external constraints. No attempt will be made to assess the extent to which, under liberalized trade, economic pressures are generating structural pressure to reduce the effectiveness of the collective bargaining regime in each country. Rather, we adopt the fairly mainstream economic view that while collective bargaining laws may not be the most important factor influencing investment decisions, they are a consideration, especially in competitions between jurisdictions that are at similar levels of development. This is because, according to one recent survey, on average, union members receive higher wages, higher union densities are associated with higher wage mark-ups, and net company profits tend to be lower in unionized firms than in non-unionized firms. ${ }^{67}$ In the absence of offsetting benefits, the lower cost jurisdiction will be preferred. The implication of this starting position, then, is that while NAFTA-style trade regimes

\footnotetext{
${ }^{66}$ Glasbeek, "Labour Relations Policy."

67 Toke Aidt and Zafiris Tzannatos, Unions and Collective Bargaining: Economic Effects in a Global Environment (Washington, D.C.: World Bank, 2002), 4.
} 
promote some downward pressure on the effectiveness of collective bargaining regimes, there is scope for other factors to shape the outcome.

\section{A. Canada}

1. The Trajectory of Collective Bargaining Law

\section{a. Legislative Change}

\section{i. Private Sector Collective Bargaining}

Collective bargaining law in Ontario has been regularly amended since the enactment of the first Wagner-Act style collective bargaining act in 1943, following a pattern that has been characterized as cautious and pragmatic. ${ }^{68}$ Typically, legislative reforms came bundled in packages that made concessions to both union and employer demands. For example, in 1980 the law was amended to require employers to deduct and remit union dues for all bargaining unit members (known in Canada as the Rand formula). In exchange, employers were empowered to force a ratification vote on their most recent offer. ${ }^{69}$

Labor law reform in the free-trade era has broken from this pattern. The New Democratic Party (NDP) formed the government for the first time in 1990 and was under pressure from its union supporters to amend the collective bargaining law. The government hoped to achieve a union-management consensus but, after lengthy consultations failed to yield a compromise, it introduced Bill 40 over the vociferous

\footnotetext{
${ }^{68}$ Joseph B. Rose, "Ontario: The Conservative Hegemony," in Mark Thompson et al., eds., Beyond the National Divide: Regional Dimensions of Industrial Relations (Montreal \& Kingston: McGill-Queen's University Press, 2003), 33.

${ }^{69}$ Eric Tucker, "Reflections on the History of Forced Ratification Votes in Ontario," (Winter 2001) 22 CRWS News 12.
} 
objections of employers. The bill was eventually passed after extended public hearings and came into force on January $1,1993{ }^{70}$ The most significant changes included expedited unfair labor proceedings, interim reinstatement of workers fired during an organizing campaign, broader provision for first contract arbitration, better union access to employees, a partial ban on replacement workers, extended job protection during strikes, and a right to picket on some third-party property. Bill 40 , however, was shortlived. The Progressive Conservative Party (PC) won a sweeping majority in 1995 and one of its highest priorities was labor law reform. Bill 7 was passed without any consultation or public hearings. Not only did it repeal the NDP reforms, but Bill 7 also introduced its own innovations, the most important being an end to the card-based system of certification (whereby unions could get certified by signing up 55\% of the members of the bargaining unit), mandating instead elections in every case. ${ }^{71}$ This was followed by another set of amendments in 1998, the most important of which was to strip the labour board of its power to order remedial certifications in the event it found that unfair labor practices prevented employees from expressing their true wishes in an election. ${ }^{72}$ This was followed two years later by Bill 139, which promoted union decertification. ${ }^{73}$ More

70 S.O. 1992 , c. 21.

${ }^{71}$ Labour Relations Act, 1995 (Bill 7), S.O. 1995, c. 1, Sch. A; Felice Martinello, "Mr. Harris, Mr. Rae and Union Activity in Ontario,” (2000) 24 Canadian Public Policy 17.

${ }^{72}$ Economic Development and Workplace Democracy Act (Bill 31), S.O. 1998, c. 8, known to its critics as the Walmart Act. This was because the stripping of the power of remedial certification was a response to its exercise by the board in a decision involving an unfair labor practice complaint against Walmart for its actions during an organizing drive at its Windsor store. See United Steelworkers of America v. Walmart [1997] OLRB Rep. 141. After extended litigation, the union eventually abandoned the bargaining rights it was awarded.

73 Labour Relation Amendment Act, 2000 (Bill 139), S.O. 2000, c. 38. 
recently, a Liberal government was elected in 2003 and in the fall of 2004 it introduced its own package of labor law reforms. If passed, the board's power to order remedial certification and to reinstate on an interim basis employees terminated during an organizing campaign will be restored. Card certification, however, would not, except in construction. $^{74}$

The history of labor law reform in British Columbia has followed a somewhat different pattern, alternating between employer-driven reforms and ones emerging from consultative processes. In 1987, prior to CUFTA, a conservative Social Credit government pushed through a set of one-sided reforms that ended card count certification, facilitated decertification, restricted picketing and boycotts, and empowered the chair of the labour commission to intervene in trade disputes. According to the then Labour Minister, Lyall Hanson, the twin goals of the law were "cost containment and international competitiveness."75 A majority NDP government was elected in 1991 and it established a bipartite labor-management consultation committee that produced a set of consensus recommendations. The government accepted these recommendations, including a return to card-based certifications. The parties could not reach a consensus on three issues and the government crafted a set of compromises. It banned replacement workers, retained most of the restrictions on picketing, and declined to implement a broader-based bargaining scheme for traditionally non-union sectors. In 1998 it enacted another set of reforms, the most important of which established sectoral bargaining for the construction industry. In 2001 a right-leaning Liberal government was elected and it

${ }^{74}$ An Act to amend certain statutes relating to labour relations (Bill 144), $1^{\text {st }}$ Reading, November 3, 2004.

75 Cited in Panitch and Swartz, From Consent to Coercion, 104. 
promptly repealed the sectoral bargaining provision and restored mandatory voting for all certifications, but retained the ban on replacement workers. ${ }^{76}$

Quebec entered the free-trade era with one of the more progressive private sector collective bargaining laws, having been the first province to ban replacement workers and make dues deductions mandatory. It also had a decree law that allowed the minister of labour to extend the application of a collective agreement to all firms, union and nonunion, that were in the same industrial and geographic sector. Since the free-trade era, there have been relatively few changes to the basic collective bargaining law and they have largely aimed to strengthen it. In 1994 the three-year maximum term was eliminated (except for first agreements) and in 2001 a more extensive set of amendments streamlined the administration of the code, better protected individual and union rights in cases of contracting out, and provided for forced ratification votes. On the other hand, the decree system has been weakened over the same period. In 1996 the act was amended to require a ministerial review of all decrees prior to their renewal to determine whether the decree impairs the competitiveness of the affected industries with enterprises outside of Quebec. In the years since this change, nearly a third of all decrees were not renewed, almost all covering manufacturing industries. By 2000, $73 \%$ of manufacturing

\footnotetext{
${ }^{76}$ Mark Thompson and Brian Bemmels, "British Columbia: The Parties Match the Mountains," in Beyond the National Divide, 97. On earlier legislative reforms, see Harry Arthurs, “The 'Dullest Bill': Reflections on the Labour Code of British Columbia," (1974) 9 University of British Columbia Law Review 280 and Paul Weiler, Reconcilable Differences: New Directions in Canadian Labour Law (Toronto: Carswell, 1980).
} 
employers and $60 \%$ of manufacturing employees formerly covered by decrees were now excluded. $^{77}$

Changes in a number of other Canadian jurisdictions reflect the unevenness observed in the three largest provinces. NDP governments in Manitoba and Saskatchewan, and a Liberal government in Ottawa have strengthened their private sector collective bargaining laws in various ways. On the one hand, there has been a shift away from card-count certifications to mandatory votes. Prior to the free-trade era only one province required votes. Since 1988 the number has increased to five (Nova Scotia, Alberta, Newfoundland and Labrador, Ontario, and British Columbia), covering about two-thirds of the labor force. ${ }^{78}$

Most commentators have concluded that Canadian private sector labor law has remained relatively stable in the free-trade era. ${ }^{79}$ While I do not fundamentally disagree with these judgments, they fail to give proper weight to the most significant overall change - the move to mandatory voting to establish majority support for union representation. Numerous studies have found that the shift from card counts to elections

${ }^{77}$ Michel Grant, "Quebec: A New Social Contract - From Confrontation to Mutual Gains?," in Beyond the National Divide, 51; Vallée and Charest, "Globalization and the Transformation of State Regulation of Labour"; Gauvin, "Labour Legislation in Canada."

${ }^{78}$ It was up to six, a newly elected NDP government repealed the 1997 mandatory vote provision in Manitoba. Percentage calculated from Statistics Canada. Labour Force Survey (January 7, 2005 release), Online at http://www.statcan.ca/english/Subjects/Labour/LFS/lfsen.htm

${ }^{79}$ Singh, "NAFTA and Labor"; Verge, "How Does Canadian Labour Law Fare"; Gauvin, "Labour Legislation". 
significantly reduces union success rates and lead to a lowering of trade union density. ${ }^{80}$ As a result, the negative effect of this change likely outweighs the positive effect of other changes.

\section{ii. Public Sector Collective Bargaining}

The picture changes dramatically if we expand our horizons to include public sector collective bargaining. Public sector collective bargaining was accepted in Canada in the mid-1960s to early 1970 s and has always differed in some respects from the private sector model, particularly with respect to dispute resolution. Strikes and lockouts were often prohibited and instead binding interest arbitration was used to resolve bargaining impasses. Public sector union density rose rapidly, far exceeding that of the private sector, and has remained high. But from early on governments often found their own legislated schemes inadequate to achieve their policy objectives and they began to enact special legislation overriding the existing labor-relations framework, including back-towork laws to end strikes and blanket wage restraints. As well, essential service designations were expanded to reduce the number of workers legally permitted to strike.

${ }^{80}$ These studies are reviewed in John Goddard, "Do Labor Laws Matter? The Density Decline and Convergence Thesis Revisited," (2003) 42 Industrial Relations 459 at 476. In addition, see Chris Riddell, "Union Certification Success under Voting Versus Card-Check Procedures: Evidence from British Columbia, 1978-1998," (2004) 57 Industrial and Labor Relations Review 493; Sara Slinn, "The Effect of Compulsory Certification Votes on Certification Applications in Ontario: An Empirical Analysis," (2003) 10 Canadian Labour and Employment Law Journal 399. 
The use of these devices increased in the 1980s, leading one commentator to characterize the regime as one of "permanent exceptionalism."

These kinds of legislative interventions have peaked during the free-trade era. Between 1991 and 1996, 11 of the 15 governments that were in power relied on special legislation to extend contracts, impose wage cuts or freezes, require workers to take unpaid leave days, or override job security provisions to facilitate downsizing. ${ }^{82}$ Since 1996 back-to-work legislation was used by British Columbia, Newfoundland, Nova Scotia Quebec, and Saskatchewan to end nurses strikes (in most cases, the government imposed its offer rather than follow the more usual practice of sending the dispute to binding arbitration). British Columbia and Alberta also passed back-to-work legislation to end teachers' strikes as did the Federal government to end strikes by its blue-collar and corrections employees. As well, the Federal government suspended interest arbitration in 1997, making strikes the exclusive method of dispute resolution. At the same time, it greatly expanded the essential service designation, the effect of which was to leave

${ }^{81}$ Leo Panitch, "Toward Permanent Exceptionalism: Coercion and Consent in Canadian Industrial Relations," (1984) 13 Labour/Le Travail 133. The argument has since been expanded and updated in a book now in its third edition: Leo Panitch and Donald Swartz, From Consent to Coercion: The Assault on Trade Union Freedoms, $3^{\text {rd }}$ rev. ed. (Aurora, ON: Garamond, 2003). Also see Joseph B. Rose, "Public Sector Bargaining: From Retrenchment to Consolidation," (2004) 59 Relations Industrielles 271 and Daniel Drache and Harry Glasbeek, The Changing Workplace (Toronto: Lorimer, 1992), ch. 9.

${ }^{82}$ Gene Swimmer, "Public-Sector Labour Relations in an Era of Restraint and Restructuring: An Overview," in Gene Swimmer, ed., Public-Sector Labour Relations in an Era of Restraint and Restructuring (Toronto: Oxford University Press, 2001), 1. 
employees with no dispute resolution mechanism short of an illegal strike. ${ }^{83}$ Rose argues that in recent years governments have maintained a hard line to better institutionalize the changes they made during the 1990s. To accomplish this result they have heavily relied on legislation that restricts the right to strike, puts controls on interest arbitration, and limits bargaining subjects. Rose concludes, "Governments are not prepared to restore a genuine collective bargaining system." 84

\section{b. Passive and Hidden Deregulation?}

Trade liberalization has spurred employers to change a range of employment practices that adversely affect the effectiveness of existing collective bargaining scheme. ${ }^{85}$ These include the use of contingent workers and the outsourcing of work. Contingent workers are more difficult to organize because they are often less attached to the workplace and also because their employment status may be uncertain, even after the extension of the collective bargaining regime to "dependent contractors." 86 Outsourcing also puts a large burden on union organizing resources. Successor rights are available in a rather narrow range of circumstances, so that when a unionized plant contracts work

${ }^{83}$ Gene Swimmer and Tim Bartkiw, "The Future of Public Sector Collective Bargaining in Canada," (2003) 24 Journal of Labor Research 579, 582-85.

${ }^{84}$ Rose, "Public Sector Bargaining," 287. Also see Panitch and Swartz, From Consent to Coercion, 183-208.

${ }^{85}$ Morley Gunderson and Anil Verma, "Free Trade and Its Implications for Industrial Relations and Human Resource Management," in Regional Integration and Industrial Relations in North America, 167, 170-2.

${ }^{86}$ Judy Fudge, Eric Tucker, and Leah Vosko, "Changing Boundaries of Employment: Developing a New Platform for Labour Law," (2003) 10 Canadian Journal of Labour and Employment Law 361; Judy Fudge et al., Self-Employed Workers Organize: Unions, Law and Policy (Montreal: McGill-Queen's University Press, forthcoming 2005). 
out, the union must re-organize the workers who are hired to perform what was previously bargaining unit work. These are not the only reasons why private sector union density has declined in Canada during the free trade era by at lest two percentage points to around eighteen percent, but it is part of the explanation. ${ }^{87}$

Flexibilization also has a significant impact on unions' bargaining power in the context of a scheme that only requires collective bargaining to occur on a workpace-byworkplace basis. The proliferation of small bargaining units not only increases the costs of bargaining, but also erodes union bargaining power. The result is that outside of a few sectors where pattern bargaining has survived, unions have been unable to take wages out of competition. As well, even within unionized workplaces, there has been a significant increase in contingent employment. For example, the percentage of newly hired employees in unionized jobs has grown from nineteen in 1989 to twenty eight in 2004. ${ }^{88}$ We will look more closely at the consequences of this development when we discuss collective bargaining itself as a mechanism of adjustment. Here it is sufficient to note that the failure to adopt broader-based bargaining schemes or other measures aimed at redressing the structural misfit between the current law governing bargaining structure

${ }^{87}$ The significance of the lack of fit between collective bargaining law and the decline in trade union density is a matter of some debate. See John O'Grady, "Beyond the Wagner Act, What Then?" in Daniel Drache, ed., Getting on Track (Montreal: McGill-Queen's University Press, 1992), 153 (pessimistic view of the viability of the Wagner Act model); Andrew Jackson, "Solidarity Forever? Trends in Canadian Union Density," (2004) 74 Studies in Political Economy 125 (structural shifts in employment had limited impact on private sector union density decline).

${ }^{88}$ René Morisette and Anick Johnson, Are Good Jobs Disappearing in Canada, (Ottawa: Statistics Canada, Analytical Studies Branch Research Paper Series, 11F0019MIE-No. 239), Table 12 . 
and changes in the labor market should be considered a form of passive labor market deregulation.

Turning to administration and enforcement, to my knowledge there is no evidence that these issues have loomed large as a mechanism of adjustment to trade liberalization in Canadian collective bargaining law. Canadian labor boards have not altered their interpretation of their enabling statutes during the free-trade era in a manner that has further limited the law's effectiveness. Of course, this is not to say that prior to the freetrade era labor relations boards single-mindedly pursued policies favorable to the growth and effectiveness of collective bargaining, ${ }^{89}$ but rather that there has not been a notable shift in the compromises embedded in board jurisprudence. Indeed, on at least some occasions, labor boards have attempted to respond to the challenges posed by employer resistance to collective bargaining and flexibilization strategies. ${ }^{90}$ In Ontario, the Conservative government threatened the independence of the labour board by changing long-standing appointment practices, but it suffered legal setbacks and other governments have not followed suit. ${ }^{91}$ Moreover, the Supreme Court of Canada has been giving labor boards greater leeway to interpret their enabling statutes in the free-trade period than had

${ }^{89}$ For a critical assessment, see Glasbeek and Drache, The Changing Workplace, 57-97.

${ }^{90}$ For example, a number of boards have found held that Walmart's tactics for resisting unionization constitute unfair labor practices. For example, see United Steelworkers of America v. Wal-Mart Canada [1997] OLRB Rep. 141; Walmart Canada and UFCW, Local 1518 [2003] BCLRBD No. 156. The Quebec labor board has adopted a more expansive approach to successor rights. See cases cited in Ivanhoe Inc. v. UFCW, Local 500 [2001] S.C.R. 565.

${ }^{91}$ Kevin M. Burkett, “The Politicization of the Ontario Labour Relations Framework in the 1990s," (1998) 6 Canadian Journal of Labour and Employment Law 161; Craig Flood, "Hewat v. Ontario," ibid, 263. 
been the case previously. ${ }^{92}$ In short, it would be difficult to claim administrative practices changed in a manner that undermined the effective of the collective bargaining scheme. ${ }^{93}$

\section{Contextual Mediations}

\section{a. Internal Adjustments: Bargaining}

The extent to which post-World War II Canadian statutory collective bargaining schemes were ever an effective vehicle for constructing a more democratic regime of industrial citizenship is a matter of considerable debate. ${ }^{94}$ What is significant, however, is that there is now widespread agreement that the aspirations of those who viewed the post-war collective bargaining scheme as a mechanism through which a new world of industrial citizenship could be created have been dashed. Even more to the point, is that globalization has been identified as one of the crucial reasons for this failure. ${ }^{95}$ Thus, at a

${ }^{92}$ On the 1980s, see Brian Etherington, "Arbitration, Labour Boards and the Courts in the 1980s: Romance Meets Realism” (1989) 68 Canadian Bar Review 405. The decision in Ivanhoe Inc. v. UFCW, Local 500 [2001] 2 S.C.R. 566, is more reflective of the court's current, less interventionist practice.

${ }^{93}$ In Ontario, the Conservative government changed the appointment/reappointment policy to the labor board that arguably undermined its independence, but there has not been a study of whether this change had an effect on the labor board's policies and practices.

${ }^{94}$ The classic articulation of this aspiration can be found in Task Force on Labour Relations, Canadian Industrial Relations Final Report (Woods Task Force)(Ottawa: Privy Council, 1968), paragraph 296. Also, see Harry Arthurs, "Developing Industrial Citizenship: A Challenge for Canada's Second Century," (1967) 45 Canadian Bar Review 786. For assessments that emphasize the limitations of the scheme, see Fudge and Tucker, Labour Before the Law; Judy Fudge and Harry Glasbeek, "The Legacy of PC 1003," (1995) 3 Canadian Labour and Employment Law Journal 357.

${ }^{95}$ H.W. Arthurs, "The New Economy an the New Legality: Industrial Citizenship and the Future of Labour Arbitration," (1999) 7 Canadian Labor and Employment Law Journal 45-63 
macro-level, it is fair to say that the collective bargaining regime has internally adapted to the broader environment in which it operates.

Turning to the micro-level of adjustment, there are a number of indicators that the predominant approach of employers has been to use forcing strategies to extract concessions at the bargaining table, rather than adopting 'high road' strategies to increase productivity through improved conditions, more participation, and greater job security. ${ }^{96}$ With respect to wages, the union-nonunion wage differential is estimated to have shrunk from approximately $25 \%$ in the late 1970 s to $8 \%$ in 1997 . Major private sector wage settlements have decreased from an average of $4.8 \%$ between 1982 and 1988 to an average of $2.6 \%$ between 1989 and 2001 . There has also been a breakdown of the linkage between productivity gains and wages increases. For example, between 1992 and 2002, productivity in manufacturing increased nearly $18 \%$ while real hourly wages increased by just $3.3 \% .{ }^{97}$ As well, pattern bargaining has been abandoned or disrupted in many industries. As these data indicate, despite making the protection of wages and benefits their top priority, unions have had limited success resisting employer demands for labor cost concessions. ${ }^{98}$ Job security and lay-off protection has become the second highest bargaining priority of unions, but few have succeeded in obtaining substantive limitations

and The New Economy and the Demise of Industrial Citizenship (Kingston: Queen's University Industrial Relations Centre, 1996).

96 Verma and Chaykowski, "Employment and Employment Relations," 12; Gordon Betcherman, "Workplace Change in Canada: The Broad Context," in Verma and Chaykowski, Contract and Commitment, 21, 27-30.

${ }^{97}$ Calucated from Panitch \& Swartz, From Consent to Coercion, Appendix I, Table II.

${ }^{98}$ Rose and Chaison, "Unionism," 45; Andrew Jackson, From Leaps of Faith to Hard Landings: Fifteen Years of 'Free Trade' (Ottawa: Canadian Centre for Public Policy, 2003), 1011. 
on contracting out or hiring contingent workers. ${ }^{99}$ Moreover, the average number of strikes per year has declined sharply from 693 between 1982 and 1988 to 409 between 1989 and 2001. ${ }^{100}$

The point is not that collective bargaining imposes no restraints on unionized employers -- unionized employees continue to enjoy a higher level of protection than non-unionized employees - but rather that in the free-trade era employers have been able to use the bargaining process as a mechanism of adjustment to the demands of a more competitive environment. Their ability to make these adjustments has reduced employer demand for weaker private sector collective bargaining laws.

\section{b. External Constraints}

\section{i. Political}

Unions in Canada have a long history of political engagement that, in the postWorld War II era, has principally taken the form of support for the NDP. Although the NDP has never formed or come close to forming the federal government, it has formed provincial governments in British Columbia, Manitoba, Ontario, and Saskatchewan, including during the free-trade era (British Columbia 1992-2001, Manitoba 1999-present, Ontario 1990-95, Saskatchewan 1991-present). During each of these periods of NDP government, private sector collective bargaining laws were modestly strengthened to meet some union demands. On the other hand, when ideologically conservative governments have been in power (Ontario 1995-2003, Alberta 1972-present, British Columbia 2001-present), private-sector collective bargaining laws have been weakened in response to employer demands. Quebec is a special case where a separatist political

\footnotetext{
${ }^{99}$ Rose and Chaison, ibid, 45-7.

${ }^{100}$ Calculated from Panitch \& Swartz, From Consent to Coercion, Appendix I, Table III.
} 
project has provided the foundation upon which to build a limited corporatist entente through which it has been possible to negotiate labor-management compromise for much of the 1990s. The election of right-leaning Liberal government in 2003 may result in private sector industrial relations becoming more contentious. ${ }^{101}$

The political orientation of the government in power has also had a significant impact on public sector labor relations, with governments led by centrist and conservative parties being far more aggressive in their resort to unilateral legislation to constrain public sector unions and limit collective bargaining than governments led by parties with a social democratic orientation. However, even left-of-centre parties have supported back-to-work legislation and other 'exceptional' interventions limiting 'normal' operation of public sector collective bargaining laws. ${ }^{102}$

\section{ii. Legal}

As noted, hard law constraints may operate at both the international and the national level. At the international level, two ILO conventions protect freedom of association, Nos. 87 and 98. Canada ratified the first in 1972 but not the second. It is generally accepted, though, that all members of the ILO are obliged to protect the right to freedom of association and this obligation was further advanced in 1998 with the adoption of the Declaration of Fundamental Rights and Principles at Work. ${ }^{103}$ The mechanisms for enforcing these obligations, even when nations have ratified the relevant

\footnotetext{
${ }^{101}$ Pantitch and Swartz, From Consent to Coercion; Thompson, Beyond the National
} Divide.

\footnotetext{
${ }^{102}$ Swimmer and Bartkiw, "Future," 583, Panitch and Swartz, passim.

${ }^{103}$ Leary, "The Paradox of Workers' Rights," 29.
} 
conventions, however, are extremely weak, depending largely on monitoring, reporting, and, ultimately, public pressure. These have proven to have little or no effect on constraining the actions of Canadian governments, particularly when dealing with public sector workers. Panitch and Swartz examined complaints made to the ILO for violations of freedom of association by G-7 countries between 1954 and 2001. During that period a total of 66 complaints have been filed against Canada, giving it the dubious distinction of having the most. Notably, 35 of these complaints were filed between 1992 and $2001 .^{104}$ The ILO Committee of Freedom of Association has repeatedly noted with regret that various Canadian governments are violating workers' freedom of association and requested that the offending legislation be repealed. These findings and requests have been ignored. ${ }^{105}$

Turning to the NAALC, it will be recalled that its enforcement provisions aim to prevent deregulation through non-enforcement of domestic law. As such, it does not purport to operate as a constraint on direct or passive labor market deregulation, although it could have an indirect effect. Perhaps for this reason Canadian unions have continued

${ }^{104}$ Panitch and Swartz, From Consent to Coercion, 54-7, 208-9. At least half-a-dozen more have been filed since.

${ }^{105}$ For example, see the most recent report of the committee of experts, CEACR: Individual Observation concerning Convention No. 87, Freedom of Association and Protection of the Right to Organise, 1948 Canada (ratification: 1972) Published: 2004, Online at http://www.ilo.org/ilolex/english/newcountryframeE.htm and the most recent report of the Committee on Freedom of Association to the Governing Body (GB 291/7, Geneva, Nov. 2004), paras. 412-512, online at http://www.ilo.org/public/english/standards/relm/gb/docs/gb291/pdf/gb7.pdf. For discussion, see Burkett et al., "Canada and the ILO," (2003) 10 Canadian Labour and Employment Law Journal 231; Ken Norman, "Promises and Paradoxes: ILO Freedom of Association Principles as Basic Canadian Human Rights,” (2004) 67 Saskatchewan Law Review 591, 604-08. 
to funnel the overwhelming majority of their complaints through the ILO rather than through the NAALC.

Two complaints have been brought against Canada under the NAALC. The first arose out of the closure of a McDonald's restaurant in Quebec, allegedly to avoid unionization. The submitters claimed that McDonald's exploited loopholes in Quebec's labor law that permits employers to delay certification proceedings and then close facilities to avoid unionization. The American NAO accepted the case for review, but shortly thereafter an agreement was reached between the submitters and the Quebec government to include this issue in a review process of the Quebec Labour Code that was already underway. As a result, the complaint was withdrawn and the file closed. In 2001 administrative changes were made to the Code that accelerated the certification process, but nothing was done to address plant closings to avoid unionization. ${ }^{106}$

The second complaint arose out of a provision in federal legislation that deems rural route mail couriers not be employees for the purposes of collective bargaining law, thereby depriving them of access to a statutory collective bargaining scheme. The American NAO refused to accept this complaint because it did not raise a question related to the enforcement of law. The rural route mail couriers subsequently achieved voluntary recognition after a lengthy and expensive organizing drive by the postal workers' union. ${ }^{107}$

${ }^{106}$ Lance Compa, "NAFTA's Labour Side Agreement Five Years On: Progress and Prospects for NAALC," (1999) 7 Canadian Labour and Employment Law Journal, 1, 22-24; personal communication with Stephanie Bernstein, 13 January 2005 (on file with author).

${ }^{107}$ Compa, ibid.; Judy Fudge et al, Self-Employed Workers Organize (forthcoming). 
In short, NAALC has been little used as a mechanism of redress in Canada and its direct impact has been quite limited. It does not restrict the power of Canadian governments to pass legislation violating freedom of association and the problem of government non-enforcement has not loomed large in the collective bargaining regime.

International law norms, hwoever, may have indirect effects, including their influence on the development of national legal norms. With this in mind, we turn to domestic legal constraints on labor market regulation, the principal one being the Charter of Rights and Freedoms, which can into force in 1982. The Charter protects freedom of association but does not define its parameters. Union supporters hoped the courts would find it protected the right to bargain collectively and to strike, while opponents hoped it would be found to limit union security clauses. Initially both sides were disappointed as the Supreme Court of Canada's refusal to constitutionalize labor rights, including the right to bargain collective and strike, left the state ample scope to craft its labor relations policy as it saw fit. ${ }^{108}$ A recent trilogy of decisions, however, indicates there has been a bit of a shift.

In Dunmore v. Ontario (Attorney General) ${ }^{109}$ the court considered a Conservative government law excluding agricultural workers from the Ontario's collective bargaining statute. The law not only deprived agricultural workers of access to a statutory collective bargaining scheme, but they also lost protection against being discharged or discriminated against for engaging in organizing activity. In earlier cases, the court had

${ }^{108}$ For a discussion of these early cases, see Dianne Pothier, "Twenty Years of Labour Law and the Charter," (2002) 40 Osgoode Hall Law Journal 369; Judy Fudge, "Labour, the New Constitution and Old Style Liberalism,” (1988) 13 Queen's Law Journal 61.

${ }^{109}$ [2001] 3 S.C.R. 1016. 
held that freedom of association is an individual right and that the state only had to refrain from barring workers from forming associations. It did not require the state to positively protect the exercise of that freedom from adverse action by non-governmental individuals and organizations. ${ }^{110}$ In Dunmore the court moderated its earlier position in two ways. First, it recognized that freedom of association protects some collective rights. Second, it also found that freedom of association sometimes requires the state to protect particularly vulnerable workers from private-party interference. In the court held that the government of Ontario was required to protect agricultural workers against unfair labor practices and that their associations had the right to make representations on their behalf to employers. This was thin constitutional protection, indeed, since it did not give them access to an effective scheme of collective bargaining, and the then conservative Ontario government responded with legislation that gave agricultural workers the bare minimum required by the court. This legislation is now being challenged and the court will be pressed to further constitutionalize collective bargaining rights. ${ }^{111}$

One particularly interesting feature of the case is that in reaching its decision the court relied on international law norms in its interpretation of the Canadian Charter's protection of freedom of association. For example, to defend the proposition that freedom of association was not just an individual right but also a collective one, Bastarache J, writing for the majority, stated:

The collective dimension of s. $2(d)$ is also consistent with developments in international human rights law, as indicated by the jurisprudence of the Committee of Experts on the Application of Conventions and Recommendations and the ILO Committee on Freedom of Association

${ }^{110}$ Delisle v. Canada (Deputy Attorney General) [1999] 2 S.C.R. 989.

${ }^{111}$ An Act to Protect the Rights of Agricultural Workers, S.O. 2002, c. 16. 
(see, e.g., International Labour Office, Freedom of Association: Digest of decisions and principles of the Freedom of Association Committee of the Governing Body of the ILO (4th ed. 1996)). Not only does this jurisprudence illustrate the range of activities that may be exercised by a collectivity of employees, but the International Labour Organization has repeatedly interpreted the right to organize as a collective right (see International Labour Office, Voices for Freedom of Association (Labour Education 1998/3, No. 112): "freedom is not only a human right; it is also, in the present circumstances, a collective right, a public right of organisation" (address delivered by Mr. Léon Jouhaux, workers' delegate) $){ }^{112}$

Further on Bastarche J. returned to international human rights law to justify the court's

holding that the Charter may prevent the exclusion of vulnerable workers from

legislation protecting the exercise of freedom of association.

The notion that underinclusion can infringe freedom of association is not only implied by Canadian Charter jurisprudence, but is also consistent with international human rights law. Article 2 of Convention (No. 87) concerning Freedom of Association and Protection of the Right to Organize, 67 U.N.T.S. 17, provides that "[w]orkers and employers, without distinction whatsoever, shall have the right to establish and ... to join organisations of their own choosing" (emphasis added), and that only members of the armed forces and the police may be excluded (Article 9). In addition, Article 10 of Convention No. 87 defines an "organisation" as "any organisation of workers or of employers for furthering and defending the interests of workers or of employers" (emphasis added). Canada ratified Convention No. 87 in 1972. The Convention's broadly worded provisions confirm precisely what I have discussed above, which is that discriminatory treatment implicates not only an excluded group's dignity interest, but also its basic freedom of association. This is further confirmed by the fact that Article 2 operates not only on the basis of sex, race,

nationality and other traditional grounds of discrimination, but on the basis of any distinction, including occupational status (see L. Swepston, "Human rights law and freedom of association: Development through ILO supervision" (1998), 137 Int'l Lab. Rev. 169, at pp. 179-180). Nowhere is this clearer than in Article 1 of Convention (No. 11) concerning the Rights of Association and Combination of Agricultural Workers, 38 U.N.T.S. 153 , which obliges ratifying member states to secure to "all those engaged in agriculture" the same rights of association as to industrial workers; the convention makes no distinction as to the type of agricultural work

${ }^{112}$ Dunmore, para. 16. 
performed. Although provincial jurisdiction has prevented Canada from ratifying Convention No. 11, together these conventions provide a normative foundation for prohibiting any form of discrimination in the protection of trade union freedoms (see J. Hodges-Aeberhard, "The right to organise in Article 2 of Convention No. 87: What is meant by workers 'without distinction whatsoever'?" (1989), 128 Int'l Lab. Rev. 177). This foundation is fortified by Convention (No. 141) concerning Organisations of Rural Workers and Their Role in Economic and Social Development (I.L.O. Official Bulletin, vol. LVIII, 1975, Series A, No. 1, p. 28) which extends, under Article 2, the freedom to organize to "any person engaged in agriculture, handicrafts or a related occupation in a rural area, whether as a wage earner or, ... as a tenant, sharecropper or small owneroccupier". ${ }^{113}$

This decision illustrates that, not withstanding its weak enforceability, 'soft' international law may influence the development of 'hard' domestic constitutional law. Of course, whether this occurs depends entirely on the predilections of domestic institutions. ${ }^{114}$

The Supreme Court also recently considered the legality of secondary picketing under common law, a dimension of labor law that we have not addressed up to now. Historically, courts had developed numerous torts to restrict picketing activity and were particularly hostile to secondary action. Indeed, in the early 1960s the Ontario Court of Appeal famously found that secondary picketing was per se tortious. ${ }^{115}$ Since 1982 unions had challenged a number of restrictions on picketing, claiming that they violated freedom of expression, but they ran into two major problems. First, in most Canadian

${ }^{113}$ Ibid, par. 27.

${ }^{114}$ For discussions of Dunmore, see the symposium in (2003) 10:1 Canadian Labour and Employment Law Journal ; Judy Fudge, “'Labour is Not a Commodity': The Supreme Court of Canada and Freedom of Association," (2004) 67 Saskatchewan Law Review 425; Jamie B. Cameron, “The 'Second Labour Trilogy'," (2002) 16 Supreme Court Law Review (Canada) $2^{\text {nd }}$ Series, 67. On the use of international law in the interpretation of domestic law, see Stéphane Beaulac, "Recent Developments on the Role of International Law in Canadian Statutory Interpretation," (2004) 25 Statute Law Review 19.

${ }^{115}$ Hersees of Woodstock Ltd. v. Goldstein [1963] 2 O.R. 81. 
jurisdictions picketing is governed by common law, not statute, and this raised the question of whether Charter applied to private litigation based on the common law. The court answered this question in the negative, although it did allow that the common law should be developed in a manner that was consistent with Charter principles. ${ }^{116}$ The second problem was that where the Charter did apply because there was state action, restrictions on protected freedoms are permissible if they are demonstrably justified in a free and democratic society. Although the Supreme Court found that picketing was a protected form of expression, it was not highly valued and in case after case the court found that restrictions on labor picketing were justified. ${ }^{117}$

The Supreme Court abruptly reversed its course in a unanimous judgment in RWDSU, Local 558 v. Pepsi-Cola Canada Beverages (West) Ltd, ${ }^{118}$ in which the court held that secondary picketing was legal at common law unless it involves conduct that is independently tortious or criminal. This was the first time that court modified the common law in order to make it conform to Charter values. Moreover, in reaching its decision, the court expressed a far more positive view of the expressive value of picketing than it had in the past. Of course, this decision still leaves in place all the economic torts, such as inducing breach of contract and civil conspiracy to injure, that provide a basis for limiting secondary activity, but it indicates some willingness by the

\footnotetext{
${ }^{116}$ RWDSU v. Dolphin Delivery Ltd. [1986] 2 S.C.R. 573.

${ }^{117}$ H.J. Glasbeek, “Contempt for Workers,” (1990) 28 Osgoode Hall Law Journal 1. ${ }^{118}$ [2002] 1 S.C.R. 156.
} 
Supreme Court to use constitutional norms to expand the scope of legally permissible collective action. ${ }^{119}$

The third case raised a question about the constitutionality of union security provisions, particularly whether mandatory union membership violated freedom of association. The claim hinges on a finding that freedom of association also protects individuals from forced association and that various forms of union security bring people into involuntary association. The court has been badly split on these issues and this was evident in its most recent decision, $R$. v. Advance Cutting \& Coring, which produced five separate judgments. ${ }^{120}$ A large majority of the court endorsed the proposition that freedom of association does encompass a negative right from forced association, but only a bare majority found that a mandatory membership provision in a Quebec statute governing collective bargaining in construction violated that guarantee. In their view, compulsory membership in a union amounted to a form of ideological coercion, even in the absence of any evidence that the union coerced members to accept the views it espoused. In the result, however, a bare majority of the justices upheld the law: one was of the view that there was no negative dimension to freedom of association; three rejected the claim that compulsory union membership violated the negative right; and one thought the violation was demonstrably justified because of the severity of the labor relations problems in the Quebec construction industry. Thus, while this law survived the

${ }^{119}$ For discussion, see Bernie Adell, "Secondary Picketing after Pepsi-Cola: What's Clear, and What Isn't," (2003) 10 Canadian Labour and Employment Law Journal 135.

${ }^{120}$ [2001] 3 S.C.R. 209. 
challenge, the court's decision provides ammunition for future challenges to union security clauses and the use of union dues for political activity. ${ }^{121}$

In sum, then, law has operated, in a limited way, to constrain downward pressure on collective bargaining schemes. While international law does not impose any enforceable limits on state action, its norms have influenced the Supreme Court of Canada's interpretation of domestic constitutional law, and led the court to strike down the Conservative government's legislation depriving agricultural workers of any protection or support for associational activities. The court has also used Charter values to roll back slightly common law restrictions on secondary action. Whether it will further constitutionalize the right to bargain collectively or to strike, however, remains to be seen. At the same time, the court has also indicated its concern to protect individuals against compelled associations.

\section{iii. Ideological/Civil Society}

An assessment of the extent to which Canadian governments are constrained from deregulating labor markets generally and weakening collective bargaining regimes in particular by popular beliefs and civil society activism is inherently difficult. In part, the election of social democratic governments in a number of provinces speaks in a general way to the level of popular discontent with the social dislocations and growing inequality that are associated with the combination of trade liberalization and neo-liberal domestic politics, but our focus here is on the extra-parliamentary activities of labor and social movements, particularly as they relate to the collective bargaining regime.

${ }^{121}$ For a discussion of this case, see Michael MacNeil, "Unions and the Charter: The Supreme Court of Canada and Democratic Values," (2003) 10 Canadian Labour and Employment Law Journal 3. 
At a national and provincial level, regressive labor legislation has often been met by large mobilizations of unions and social movements. In Ontario, for example, the labor movement launched a series of one-day municipal-wide general strikes in response to the Conservative government's labor law reforms. Social movements joined the cause, bringing in their concerns about other government policies, producing unprecedented displays of solidarity. In Toronto, nearly a million people took to the streets. Yet the movement fizzled, in part because of internal tensions between public and private sector unions. $^{122}$ In subsequent years two massive public sector strikes, one a legal strike by provincial government employees, the other an illegal province-wide strike by Ontario teachers opposed to legislation that, inter alia, weakened their collective bargaining rights, also attracted widespread public support, but did little to deter the government from pursuing its agenda, although it may have moderated the use of legal coercion against the strikers. ${ }^{123}$

Trade liberalization and the growing economic integration of Canada, the United States, and Mexico has encouraged the development of transnational union and social movement activism. For example, it has been suggested that the greatest contribution of the NAALC complaint process is not the case results, but the deepening of ties between national labor movements. ${ }^{124}$ Yet despite the growth of this activism, it would be difficult to argue that it has exercised a constraining force on the Canadian state. In large

${ }^{122}$ Marcella Munro, "Comment on Ontario's Days of Action and Strategic Choices for the Left in Canada," (1997) 53 Studies in Political Economy 125.

${ }^{123}$ David Rapaport, No Justice, No Peace: The 1996 OPSEU Strike against the Harris Government (Montreal: McGill-Queen's University Press, 1999); Harry Glasbeek, “Class Wars: Ontario Teachers and the Courts," (1999) 37 Osgoode Hall Law Journal 813.

${ }^{124}$ Ayres, "Power Relations," 110; 
measure, this is because activists have not targeted Canada. Rather, transnational activism has aimed at labor market regulation and enforcement in Mexico and other less developed countries, the labor practices of multinational corporations and their contractors, and developments in the laws and institutions governing international trade. To the extent that cross-border resistance is successful, this relieves some of the pressures that may otherwise promote Canadian labor market deregulation, but its effects are quite indirect.

\section{Conclusion}

The trajectory of Canadian labor law has not been as even-keeled as the new consensus supporters have argued. While it is true that private sector labor laws have ebbed and flowed over the past fifteen years, depending on the party in power, it is arguable that the negative effects of certification procedure changes have outweighed the positive effects of more union-friendly amendments. This is reflected in the decline in union density during the free-trade era. The inclusion of public sector collective bargaining legislation shifts the trajectory of labor law change in a sharply downward direction, as governments across Canada have unilaterally acted to curb collective bargaining by public and para-public sector employees. The picture becomes even bleaker if we expand our focus to the effectiveness of labor market regulation, taking into account passive deregulation. The Canadian labor market has changed substantially over the past fifteen years, changes accelerated by trade liberalization. Collective bargaining legislation has not responded to the challenges posed by work restructuring, even when left-center parties have been in power. Administrative or disguised deregulation has not loomed large 
Yet, it is also the case that the downward trajectory of collective bargaining law has not been as steep as many free-trade critics predicted. This is because of internal accommodations and external restraints. Internal accommodation is built into free collective bargaining, which is designed to be responsive to changes in bargaining power. The maco-level role of collective bargaining as promoter of industrial democracy has largely yielded to its more limited bargaining role, but in a context in which union bargaining power has been eroded. As a result, unionized employers have been able to implement flexibilization and cost-cutting strategies, albeit not without resistance. For those who view collective bargaining as a mechanism for protecting labor standards this is not good news, but it does help explain why the pressure for legal deregulation may have been blunted. Indeed, it is arguable that because market discipline does not operate as effectively on the public sector that governments have been more inclined to use legislation to achieve their objectives. External influences, however, have exerted some moderating pressure. In particular, there is considerable political support for parties that articulate an alternative to the neo-liberal vision of a world governed by market forces. Where left-center parties are elected, the private sector collective bargaining regime has been sustained and there is somewhat less frequent resort to coercive legislation in the public sector. International and domestic constitutional law have exerted a weak, moderating effect, most clearly exhibited in the Dunmore decision imposing a positive obligation on the state to protect the exercise of freedom of association for vulnerable workers. Finally, while there have been major civil society mobilizations to oppose trade liberalization, and sporadic mass demonstrations against anti-union labor legislation, its restraining effects have been limited. 


\section{B. United States}

1. Trajectory of Labor Market Regulation

\section{a. Legislative Change \\ i. Private Sector}

The most notable characteristic of American private collective bargaining legislation is that it has not changed in any major respect since at least 1959 and that its basic text dates from 1935 and $1947 .{ }^{125}$ Legislative inaction is not the result of a lack of effort, largely on the part of unions, to amend the law. Rather, it is primarily caused by organized employers mobilizing enough support in Congress to block any amendment proposed by labor. Clearly, employer opposition to union-sponsored labor law reform predates NAFTA, so it cannot be said that legislative inertia is one of NAFTA's effects, although it is fair to surmise that in the post-NAFTA environment employers' resolve to resist labor law reforms, such as a prohibition on the permanent replacement of striking workers, has only been strengthened. ${ }^{126}$ Therefore, an assessment of NAFTA's impact on the effectiveness of private sector collective bargaining must shift to passive and administrative forms of deregulation.

\section{ii. Public Sector Collective Bargaining}

125 Cynthia Estlund, "The Ossification of American Labor Law," (2002) 102 Columbia Law Review 1527, 1530. Organized labor was able to block the one employer-initiated reform in the post-NAFTA era, aimed at weakening the prohibition on employer-sponsored representation and participation programs

${ }^{126}$ Two bills containing this prohibition gained majority support in Congress in 1992 and 1994, but in each case were filibustered to death in the Senate. Estlund, "Ossification," 1541. 
Jurisdictional arrangements over public sector bargaining in the U.S. are extremely decentralized. As a result, collective bargaining rights are "a crazy-quilt patchwork of state and local laws, regulations, executive orders, court decisions, and attorney general opinions." 127 Like in Canada, public sector collective bargaining laws were first passed in the 1960s and were adapted from the private sector model, subject to a variety of limitations regarding the scope of bargaining and dispute resolution.

Unionization in the public sector spread rapidly and union density rose sharply as private sector density fell.

Because of its decentralized character, public sector labor law is much more responsive to changes in the political orientation of the government in power. As a result, changes in public sector labor law have been diverse, making it difficult to identify an overall trend. Belman et al, argue that public sector collective bargaining has moved from a period of maturation to one of transition, and that its future direction will be shaped by two competing strategies, one involving a best practices approach, the other cost-cutting and downsizing. ${ }^{128}$ In the former scenario, public sector collective bargaining may fare well, while in the later it is likely to be restrained.

Federal government labor law provides a good example of how shifting political fortunes influence the direction of change. The Clinton administration issued Executive Order 12871 in 1993. It aimed to improve government efficiency through partnership arrangements with its unionized employees. Under this regime, union membership and

${ }^{127}$ John Lund and Cheryl Maranto, "Public Sector Labor Law: An Update," in Dale Belman et al., eds., Public Sector Employment in a Time of Transition, 21, 21; James T. Bennett and Marick F. Masters, “The Future of Public Sector Labor-Management Relations, (2003) 24 Journal of Labor Research 533, 533-35.

${ }^{128}$ Belman et al., "Public Sector Employment," 2. 
density increased in the federal public service. The Bush administration was opposed to working with unions and repealed EO 12871. As well, his administration sought and gained the power to exclude unions from agencies handling public security issues. As a result, in recent years federal sector union density has been declining. ${ }^{129}$

At the state level, the picture is quite mixed. As of 2002 there were 27 states that did not have public sector collective bargaining laws, although provision existed in some of those states for collective bargaining under local ordinances or executive orders. This is largely unchanged from the situation in $1987 .{ }^{130}$ Collective bargaining rights were extended to public sector workers in a number of states by executive order (eg. Maryland and Kentucky), but in at least one state, Indiana, the public sector collective bargaining scheme was terminated by executive order. ${ }^{131}$ Belman et al. conclude that "the pronounced trend since 1987 has been toward circumscription of bargaining and toward support for unilateral action by government" ${ }^{132}$ but it would appear that the retrenchment in the US is not as severe as it has been in Canada.

\section{b. Passive and Administrative Deregulation}

${ }^{129}$ Robert Tobias, "The Future of Federal Government Labor Relations and the Mutual Interests of Congress, the Administration, and Unions," (2004) 25 Journal of Labor Research 19.

${ }^{130}$ Joyce M. Najita and James L. Stern, "Introduction and Overview," in Joyce M. Najita and James L. Stern, eds., Collective Bargaining in the Public Sector: the Experience of Eight States (New York: M.E. Sharpe, 2001), 3,5; Steven Kreisberg, “The Future of Public Sector Unionism in the United States," (2004) 25 Journal of Labor Research 223, 226-7.

${ }^{131}$ Kreisberg, "Future," 223-5; Kevin Corcoran and Mary Beth Schneider, "Governor says no to bargaining," (11 January 2005) Indianapolis Star (Online).

132 Belman et al., "Public Sector Employment," 10. 
The real story of private sector American labor law is not that it has been stripped down by legislative change (at least not since 1959), but rather that it has been rendered ineffective in promoting collective bargaining or even in protecting basic worker rights to freedom of association. The process of erosion, however, was already well advanced long before NAFTA. Private sector union density hovered around the 30 percent range until about 1970, when it began dropping sharply. Thus, when Paul Weiler published his well-known piece documenting the failings of the Wagner Act in 1983, he was looking back over a decade in which private sector density had dropped to about 20 percent in 1980. Private sector union density has continued to decline and since the beginning of the free trade era it has shrunk another 25 percent, falling below 9 percent in in $2002 .{ }^{133}$

There is a great debate over the causes of this decline and whether and to what extent it is attributable to the deficiencies of collective bargaining law and its administration, particularly in the face of growing employer resistance to unionization. It is beyond the scope of this article to review that literature, but there seems to be fairly compelling evidence that law does matter and that its failings explain some significant part of in the decline of private sector unions. ${ }^{134}$ In particular, the US system of drawnout certification elections and the lack of adequate protection against unfair labor practices have been noted as major impediments to successful organizing drives in the face of employer hostility, while the grant of legal authority to employers to hire permanent strike replacements and the restriction on unions from engaging in secondary

${ }^{133}$ Paul Weiler, "Promises to Keep: Securing Workers' Rights to Self-Organization Under the NLRA," (1983) 96 Harvard Law Review 1769; Goddard, "Do Labor Laws Matter," 465; US Census Bureau, Statistical Abstract of the United States: 2003, Table No. 656.

${ }^{134}$ For a useful overview, see Bruce Nissen, "The Recent Past and Near Future of Private Sector Unionism in the U.S.: An Appraisal,” (2003) 24 Journal of Labor Research 323, 323-28. 
action have been identified as major causes of weakened union bargaining power. ${ }^{135}$ These shortcomings are, in part, embedded in statute's text, but they are also the product of decades of administrative and judicial decision-making. ${ }^{136}$ Thus, in the U.S. context, it is perhaps artificial to distinguish between passive and administrative deregulation.

This is not to say that the NLRB and the courts are relentlessly anti-union in their decision-making. The NLRB has become far more politicized than Canadian labor relations boards and thus there are much greater shifts in decision-making when a new administration takes office. ${ }^{137}$ For example, the current Bush board has been accused of exhibiting a strong employer bias in recent decisions that have, inter alia, overruled Clinton board decisions that facilitated bargaining by graduate teaching assistants and contingent workers. ${ }^{138}$ Courts, too, have shifted over time in their review of NLRB decision-making, but for many years they have tended to give priority to individual rights over the promotion and preservation of collective bargaining relationships. ${ }^{139}$ The

${ }^{135}$ Weiler, "Promises to Keep"; Paul Weiler, "Striking a New Balance: Freedom of Contract and the Prospects for Union Representation," (1984) 99 Harvard Law Review 351, 412 9; Risa Lieberwitz, "Labor Law in the United States: The Continuing Need for Reform," (2004) 46:4/5 Managerial Law 53; Fantasia and Voss, Hard Work, 63-77.

136 James A. Gross, Broken Promise: The Subversion of U.S. Labor Relations Policy, 1947-1994 (Philadelphia: Temple University Press, 1995); Estlund, “Ossificiation,” 1558-69.

137 Joan Flynn, “A Quiet Revolution at the Labor Board: The Transformation of the NLRB, 1935-2000," (2000) 61 Ohio State Law Journal 1361; Gross, ibid.

138 Steven Greenhouse, "Labor Board Detractors See Bias Against Workers," New York Times, January 2, 2005, 12.

139 James J. Brudney, “A Famous Victory: Collective Bargaining Protections and the Statutory Aging Process," (1996) 74 North Carolina Law Review 939; Ellen J. Dannin and Terry H. Wagar, "Lawless Law? The Subversion of the National Labor Relations Act," (2000) 34 Loyola of Los Angeles Law Review 197 (focusing on the deleterious effect of the court-developed 
general picture that emerges is one of a regime that has become sclerotic through a combination of statutory gridlock, the weight of past decisions, and judicial constraints. $^{140}$

If American labor law was already ineffective at the beginning of the free-trade era, changes in the labor market since then have only exacerbated the problem. Much of the success of the US labor movement was premised on its ability to take wages out of competition by, in effect, organizing entire industries. As free trade agreements unleash competitive forces, and governments deregulate sectors of the economy like inter-state trucking and airlines, unions can no longer sustain that position, with the result that unionized employers often find themselves at a competitive disadvantage. ${ }^{141}$ The result, as Stone notes, is that "As firms find themselves in a more competitive environment through increased trade and global competition, they have to pay more attention to shortterm cost reduction." 142 For non-union firms, union avoidance looms as an even higher priority than it did previously. According to a study of union certification campaigns in 1998 and 1999, more than half the targeted employers threatened to move or shut-down

doctrine that allows employers to implement final offers on reaching an impasse on collective bargaining relations).

${ }^{140}$ Estlund, "Ossification," 1558-69.

${ }^{141}$ Samuel Estreicher, "Labor Law Reform in a World of Competitive Product Markets," (1993) 69 Chi-Kent L.Rev. 3, 12-15.

${ }^{142}$ Katherine V.W. Stone, From Widgets to Digits (Cambridge: Cambridge U.P. 2004), 86; Joel Cutcher-Gershfeld and Thomas Kochan, "Taking Stock: Collective Bargaining at the Turn of the Century," (2004) 58 Industrial and Labor Relations Review 3, 20 (international competition and pressure for flexibility are important drivers of systemic work practice changes); Rose and Chaison, "Unionism," 47-49. 
operations in response to union activity. ${ }^{143}$ Growing competitive pressure has also promoted reliance on flexibilization strategies, including outsourcing and the growth of contingent and precarious employment, ${ }^{144}$ all of which undermine the effectiveness of collective bargaining law which was constructed on the norm of the standard employment relation that offered workers long-term, reasonably secure employment with a large employer. The new labor market places enormous demands on unions to continuously organize new and small bargaining units, often populated by contingent and precarious workers whose employment status may be uncertain, and to negotiate collective agreements with small firms operating in highly competitive environments. ${ }^{145}$ Thus, while a number of scholars have found that trade liberalization is not a major direct cause of deunionization, they have argued that its indirect effects are significant. ${ }^{146}$

In short, it is hardly a cause for celebration to say that the rights of U.S. workers under its private sector collective bargaining laws have not been eroded by legislative change during the free-trade era. The effectiveness of U.S. labor law was already close to the proverbial bottom prior to the free-trade era, so it is not surprising that employers

${ }^{143}$ Kate Bronfenbrenner, "Uneasy Terrain: The Impact of Capital Mobility on Workers, Wages and Union Organizing," (Commissioned research paper for the U.S. Trade Deficit Review Commission, September 2000).

144 Paul Osterman et al, Working in America (Cambridge: MIT Press, 2001), 33-44; Lawrence Mishel et al, The State of Working America 220/2003 (Ithaca: Cornell University Press, 2003), 250-62 (showing some declines in 1995-2000 but indications that increasing in current labor market recession).

${ }^{145}$ Stone, From Widgets, 67-86, 196-216.

146 Robert E. Baldwin, The Decline of US Labor Unions and the Role of Trade (Washington DC: Institute for International Economics, June 2003) (small portion of union decline due to trade-induced sector shifts); Nissen, "Recent Past," 326 (globalization negatively affects social regulation). 
have not pursued labor law reform as a means of adjustment to the pressures of globalization. Rather, their lobbying energies have been directed at blocking unionsponsored labor law reforms that would respond to the well-documented inability of the scheme to promote collective bargaining and protect freedom of association in today's labor market. The growing mismatch between the legal regime and the world of work that it is intended to regulate justifies characterizing what has happened as a case of passive and administrative deregulation par excellence.

\section{Contextual Mediations}

\section{a. Bargaining}

While it has been argued that the Wagner Act was conceived as an ambitious attempt to construct a more democratic and cooperative workplace, there is little dispute that, at best, American collective bargaining has become a vehicle through which unions and employers negotiate work rules, wages, and benefits. This occurred well before the free trade era, so our focus here will be on collective bargaining outcomes. ${ }^{147}$

As in Canada, a number of indicators suggest that employers have used the collective bargaining process to extract concessions. Recent data indicate that although unionized workers still make more than their non-union counterparts, the wage differential has narrowed. During the period from 1991 to 2000 the wages of non-union

147 Mark Barenbergy, "The Political Economy of the Wagner Act: Power, Symbol, and Workplace Cooperation," (1993) 106 Harvard Law Review 1379 (arguing Senator Wagner sought to construct a cooperative social democracy); Katherine Stone, "The Post-War Paradigm in American Labor Law, “ (1981) 90 Yale Law Journal 1509 (arguing that Act treated a bare legal framework to facilitate private ordering by management and labor); Karl E. Klare, "Judicial Deradicalization of the Wagner Act and the Origins of Modern Legal Consciousness," (1977-78) 62 Minnesota Law Review 265 (Act's transformative potential defeated). 
workers increased faster than those of unionized workers. ${ }^{148}$ The linkage between productivity gains and union wage increases has been broken as capital is extracting a larger share of productivity growth. ${ }^{149}$ Work stoppages are becoming less frequent. For example, in 1989 there were 51 strikes idling 1,000 or more workers, but only 15 in 2004. ${ }^{150}$ These data suggest that employers are taking economic advantage of unions' declining bargaining power.

We also need to consider the extent to which collective bargaining has accommodated work restructuring within unionized firms. According to one survey, in 1999 new work flexibility arrangements were achieved in one-third to one-half of negotiations, while new job security provisions were made in one-tenth to one-quarter of collective agreements. Even more troubling was that less than ten percent of respondents reported that they had somewhat or very cooperative relations and that their relationship was improving. ${ }^{151}$ The picture that emerges from this study is that while innovative contract language is being negotiated, this is often the result of management forcing its agenda onto the union without providing workers with the job security or wage increases that they seek. The result is adjustment, but of an imbalanced, not a progressive, kind; the product of changing power relations more than the negotiation of mutual gains along the high road.

${ }^{148}$ Ann C. Foster, "Differences in Union and Nonunion Earnings in Blue-collar and Service Occupations" (U.S. Department of Labor, Bureau of Labor Statistics, June 25, 2003) online at http://www.bls.gov/opub/cwc/cm20030623ar01p1.htm.

\footnotetext{
${ }^{149}$ Mishel et al., State of Working America, 86-94, 156-58.

${ }^{150}$ Department of Labor, Bureau of Labor Statistics, Series WSU 100.

${ }^{151}$ Cutcher-Gershenfeld and Kochan, "Taking Stock," 9-10, 22.
} 


\section{b. External Constraints}

\section{i. Political Constraints}

Unlike in Canada, where governments have regularly modified collective bargaining legislation to make it better accord with its political orientation, in the U.S. private sector collective bargaining law has been frozen. Deregulation of collective bargaining has not occurred through direct legislative action, but rather has been passive and administrative. The political problem, therefore, has not been to block legislative deregulation, but to reverse the downward trajectory of the regime through remedial legislation. This has been beyond the means of the American labor movement.

In part, this is because the federal government must amend private sector collective bargaining. This deprives the union movement of the opportunity to have changes made in those states where it has greater influence. As well, social-democratic parties have no presence on the American political scene and the labor movement has traditionally channeled its political energies into support for the Democratic Party. Yet even during Democratic administrations, the labor movement has been unable to get any part of its collective bargaining reform agenda passed. The strength of employer resistance to unionization in their own firms is carried over into the political arena, where employers are firmly united in their opposition to any law reform that might make the collective bargaining regime more effective. In these circumstances, there is little prospect that in the foreseeable future a weakened labor movement will be able to mobilize the political resources necessary to get any part of its reform agenda enacted 
into law. ${ }^{152}$ In sum, electoral politics have not acted as a brake on the deterioration of the U.S. private sector collective bargaining regime.

\section{ii. Legal}

International law has had even less influence in the United States than in Canada. Although the United States has not ratified either of the ILO's core conventions respecting freedom of association (Conventions 87 and 98), it supported the ILO Declaration of Fundamental Principles and Rights at Work, which includes freedom of association. As well, member countries are bound to respect the principles of conventions 87 and 98 even if they have not ratified them. and the United States has accepted the jurisdiction of the ILO Committee on Freedom of Association (CFA) to review complaints filed against it, even though it is not subject to the fuller review process that applies to countries that have ratified these conventions.

While the U.S. accepts these international rights in principle, it feels free to depart from them in practice. In 1990 the CFA upheld two complaints against the U.S., one challenging the right of employers to hire permanent replacements for striking workers and the other challenging state laws prohibiting public sector unionization and collective bargaining. The government took no action to bring its laws into compliance with ILO standards. Since then US trade unionists have not brought any further complaints. ${ }^{153}$

\footnotetext{
152 Estlund, "Ossification, 1540-45.

153 Lance Compa, "Workers Freedom of Association in the United States: The Gap between Ideals and Practice," in James A. Gross, ed., Workers’ Rights as Human Rights (Ithaca, NY: Cornell University Press, 2003), 23, 28-30; Burkett et al., "Canada and the ILO,” 260-64. For a more positive assessment, see Anthony G. Freeman, "ILO Labor Standards and U.S. Compliance," (1999) 3:1 Perspectives on Work 28.
} 
The NAALC has also had little impact on American labor law. To date, eight complaints have been filed against the U.S., seven with the Mexican NAO and one with the Canadian. Six of these related to freedom of association. The first was launched in 1995 and involved the closure of a Sprint plant, allegedly to avoid unionization. Ministerial consultations produced an agreement to keep the Mexican Secretary of Labor informed of the legal proceedings underway in the United States, to instruct the NAALC secretariat to study the effects of sudden plant closures on freedom of association, and to hold a public forum in San Francisco, the site of the closure. In December 1996 the NLRB ruled that the plant closing was motivated by anti-union animus, but the United States Court of Appeal overturned decision in November 1997. The NAALC secretariat's report, issued in April 1997, found that threats of plant closing to resist union organizing efforts were widespread in the United States but less prevalent in Canada and Mexico. $^{154}$

Four complaints were filed in 1998, three of which raised freedom of association issues. ${ }^{155}$ All three were resolved by the signing of a ministerial agreement that included an undertaking to hold a government-to-government meeting to discuss the application of US law in the areas raised by the submission. As well, public outreach and education

${ }^{154}$ Mexico NAO Submission 9501 (Sprint); Mazuyer, "Labor Regulation,” 251; Lance Compa, "NAFTA's Labour Side Agreement Five Years On: Progess and Prospects for the NAALC," (1999) 7 Canadian Labour and Employment Law Journal 1, 17-19; Human Rights Watch, Trading Away Rights: The Unfulfilled Promise of NAFTA's Labor Side Agreement (New York: Vol. 13, No. 2 (B), April 2001), 40.

${ }^{155}$ Mexico NAO Submission 9801 (SOLEC); 9802 (Washington Apple Growers); and 9803 (DeCoster Egg). The fourth, Mexico NAO Submission 9804 (Yale/INS) related to the rights of migrant workers to minimum wages. 
sessions were organized in two of the localities where the alleged violations occurred to inform the public of the workers' legal rights. In 1999 the Canadian NAO declined to accept a submission alleging violations of the NLRA and in 2003 the Mexican NAO accepted a submission alleging violations of numerous workers' rights, including freedom of association. ${ }^{156}$

The results of the complaints process have been disappointing, to say the least. As one commentator noted, "up to now all cases have ended with ministerial consultations and the joint agreement of action programmes that have not produced visible changes in the legal practices of the countries concerned." ${ }^{157}$ In part this is a function of the NAALC's design, since complaints about freedom of association, collective bargaining and the right to strike cannot go past the first stage of ministerial consultations. The result is that disputes are resolved at the political level in a context in which no government has an interest in pursuing high intensity conflict strategies. ${ }^{158}$ Not surprisingly, activists are losing interest in using the NAALC and few new submissions are being filed.

This still leaves open the possibility that international labor and human rights norms exert an indirect influence through domestic constitutional and common law, as we saw in Canada. This has not been the case in the US. The US constitution does not

${ }^{156}$ Canada NAO Submission 99-1 (LPA); Mexico NAO Submission 2003-1 (North Carolina). The background to the latter submission is discussed in Compa, "Workers' Freedom," 47-48.

${ }^{157}$ Dombois et al., "Transnational Labor Regulation,” 430. For similar conclusions, also see Human Rights Watch, Trading Away Rights; Andrias, "Gender, Work," Summers, "NAFTA's Labor."

${ }^{158}$ Dombois et al, ibid, 430-35. 
protect freedom of association as such, and so attempts to ground labor rights in the constitution have had to point to other protected rights. None of these avenues have provided a basis for constitutionalizing labor rights. Indeed, opponents of collective labor rights have had more success invoking constitutional protection for the right of individuals to refrain from compelled association. ${ }^{159}$ As well, international labor and human rights norms have not influenced the courts' constitutional interpretations in this area, or in others ${ }^{160}$ and there is also no indication that US courts are likely to exercise their powers of statutory interpretation or develop the common law in ways that would better protect workers' freedom of association. In sum, neither international nor domestic law has operated as an external constraint on the decline of the collective bargaining regime.

\section{iii. Civil Society Restraints}

As noted in our discussion of Canada, it is inherently difficult to assess the extent to which governments are constrained by popular beliefs and social movement activism. On the domestic front, the labor movement, in coalition with other social movements, has scored some successes in their opposition to the free-trade agenda. It vigorously opposed NAFTA, and was largely responsible for creating a political environment in which thencandidate Clinton felt constrained to make his support for NAFTA conditional on the negotiation of a side accord protecting labor and the environment. As well, in the fall of 1997 and in 1998, the labor movement successfully lobbied to block the grant of fast-

${ }^{159}$ Estlund, “Ossification,” 1579-87.

${ }^{160}$ Catherine Powell, "Dialogic Federalism: Constitutional Possibilities for Incorporation of Human Rights Law in the United States," (2001) 150 University of Pennsylvania Law Review $271,257-58$. 
track trade negotiation authority to Clinton. ${ }^{161}$ The labor movement also played a key role in organizing the protests at the WTO meetings in Seattle that led Clinton to float the idea of linking trade to labor rights. Those successes, however, were short-lived. In 2000 the House approved a trade deal with China and in 2002 President Bush was granted fast-track authority, albeit with a provision that allows labor and environmental issues to be addressed in the agreement. This has taken the form of NAALC-type provisions that express a principled commitment of the parties to core labor standards, but only requires each party to enforce its existing laws while excusing weaknesses due to reasonable exercises of discretionary power and bona fide decisions regarding the allocation of resources. ${ }^{162}$

While these efforts aim to protect American labor from 'unfair' competition, they do so in a way that is oriented toward addressing poor conditions outside of the country. They do not address directly the declining efficacy of the US labor law regime. In large part, this is because the labor movement recognizes that labor law reform is not achievable under current conditions. Therefore, it has set about trying to rebuild itself organizationally, often through the use of tactics that by-pass the NLRA framework. This brand of social movement unionism has produced some notable successes, but has

161 James Shoch, "Organized Labor versus Globalization,” in Lowell Turner et al., eds., Rekindling the Movement: Labor's Quest for Relevance in the Twenty-First Century (Ithaca: ILR Press, 2001), 275; Ayres, "Power Relations," 107-08.

${ }^{162}$ Kimberly Ann Elliot, "Labor Standards, Development and CAFTA,” (Institute for International Economics, International Economics Policy Briefs, Number PB04-2, March 2004); Summers, "Battle of Seattle." 
yet to reverse the decline in private sector unionism. ${ }^{163}$ Absent such revitalization, there is little prospect that unions acting in concert with other social movements will be able effectively to constrain the pressures undermining the efficacy of American labor law.

Transnational activism, as we noted in our discussion of Canada, has developed, in part stimulated by the NAALC complaints mechanism, which encourages transnational collaboration. The U.S.-Mexican border has been the site of much of this activity. ${ }^{164}$ Its primary focus, however, has been on Mexican labor practices, or, if we go beyond the NAFTA framework, labor practices in the undeveloped world, rather than in the US. This is not intended as a criticism, but merely as an observation in support of a simple point: transnational civil society activism exerts no pressure on the US government to staunch the erosion of its collective bargaining regime.

\section{Conclusion}

An assessment of the trajectory of US collective bargaining law must start from the fact of its weakened state at the beginning of the free-trade era. It might be said that because it started closer to the bottom, it would not be as strongly affected by regulatory competition as Canada, the jurisdiction with higher labor standards. There is indeed an element of truth to this; US employers have not made any significant effort to amend the NLRA in the free-trade era. However, the lack of legislative change does not establish that the collective bargaining regime's efficacy is unaffected by globalization. While

${ }^{163}$ Rick Fantasia and Kim Voss, Hard Work: Remaking the American Labor Movement (Berkeley: University of California Press, 2004); Hoyt N. Wheeler, The Future of the American Labor Movement (Cambridge: Cambridge University Press, 2002).

${ }^{164}$ David Bacon, The Children of NAFTA: Labor Wars on the U.S./Mexico Border (Berkeley: University of California Press, 2004). 
U.S. collective bargaining law has not been racing downwards, increased global competitiveness has changed the labor market in ways that are antithetical to its ability to promote collective bargaining and protect workers' freedom of association. The growing mismatch between law and the social reality in which it operates produces greater regulatory failure. Public sector collective bargaining has also been adversely affected by the adoption of neo-liberal policies that are associated with the competitiveness agenda, but retrenchment does not seem to be as severe in the U.S. as it has been in Canada.

The impact of liberalized trade on collective bargaining law, however, is mediated by internal and external factors. Internally, the collective bargaining process has accommodated employer-initiated demands for concessions and greater flexibility, although it would take further study would to determine whether Canadian unions have been more successful at protecting their members than their U.S. counterparts.

Externally, political constraints have operated to prevent enactment of the remedial legislation required to slow or reverse its erosion through what can best be characterized as malign neglect. As well, international law has little or no influence on the direction of U.S. labor law, and there seems little prospect that courts will constitutionalize labor rights or otherwise protect them through their power to interpret statutes and develop the common law. Finally, civil society activism in the labor rights area is largely directed outwards, rather than inwards on domestic labor policy.

\section{Conclusion: Have Great Expectations Been Defeated?}

If the great expectation was that NAFTA would produce dramatic and significant legislative erosion of collective bargaining laws, then it is fair to say that that expectation has been partially defeated. In the U.S. the NLRA has not been amended during the free- 
trade era, and, to the extent that it is possible to discern a trend, public sector collective bargaining law has suffered relatively modest setbacks. The expectation of erosion was stronger for Canada, the jurisdiction with the higher labor standards, and while there has not been a race to the bottom in labor legislation, there has been deterioration. While private sector collective bargaining laws have been both strengthened and weakened at different times and in different places, the most significant trend has been the elimination of card-check certifications in a many jurisdictions, including Ontario and British Columbia. As numerous studies have shown, this change is likely to have a significant and negative impact on trade union density. Moreover, if we expand our focus to include public sector collective bargaining, we find the level of legislative erosion even greater as the frequency with which Canadian governments override or reduce existing collective bargaining rights has increased in the past decade.

The extent of defeated expectations is even less if we shift our focus from legislation to regulatory effectiveness. U.S. collective bargaining law was notoriously ineffective going into the free-trade era and has only become more so as trade-linked changes to the labor market have created an environment that is even more inimical to the creation and perpetuation of collective bargaining relationships. A similar situation prevails in Canada, although it is moderated somewhat by stronger and better-enforced labor rights.

This partial vindication of the predictions of Model 1 still leaves us with the need to explain why great expectations were partially defeated. The contextual variables introduced by Model 2 led us to examine factors internal to the system of collective bargaining and ones external to it. Collective bargaining is itself a mechanism of 
adjustment that accommodates changing goals and objectives that are either in the mutual interest of the parties or are backed by one party's superior bargaining power. In both Canada and the United States there is evidence that both these kinds of accommodation are occurring, largely in response to employer initiatives aimed at cutting labor costs and increasing productivity. While in some cases this results in labor-management cooperation and mutual gains, the evidence suggests that the more frequent from of accommodation involves labor concessions to management demands. While some might characterize this outcome as a regulatory failure, I have treated it as accommodation within the system on the ground that private sector collective bargaining regimes in both countries were intended to be responsive to changing economic and labor market conditions.

Differences between Canada and the United States are, perhaps, most marked in relation to the influence of external factors. Because labor law in Canada is provincial rather than national, it has been more sensitive to local swings in political strength and hence labor law reform has been more volatile. Conservative governments have taken steps to 'Americanize' labor laws, particularly in the important area of certification procedures, but NDP and most Liberal governments (BC is an exception) have resisted that pressure and, indeed, have often passed legislation that moderately strengthens the private sector collective bargaining regime. They have been less charitable when it comes to their own workers. In the US, there is little prospect that in the foreseeable future labor will be able to muster political support for long-needed reforms.

International or transnational legal regimes are ineffective in directly countering downward pressure on collective bargaining law in both Canada and the U.S. However, 
the Supreme Court of Canada has chosen to take international law seriously and use it as a point of reference in its interpretation of Canadian constitutional law. Depending on how far they go, this approach could lead to a constitutionalization of some parts of the collective bargaining regime, possibly including the right to have effective access to a statutory bargain collectively scheme. As well, the court has recently identified trade unions as socially desirable institutions whose activities, like picketing, are worthy of constitutional protection. There is little prospect that American courts will protect labor rights to the same extent.

Finally, social movements in both countries have been active in opposing globalization and neo-liberal restructuring, although it is arguably the case that protest actions aimed at regressive private sector labor law reforms and interference with public sector workers' collective bargaining rights have been stronger in Canada than in the U.S. Yet, social movement mobilizations or their threat do not seem to have had much effect on domestic collective bargaining policy. Social movements, however, have scored some success in getting social and labor issues onto the table in international trade talks and in pressuring transnational corporations to take some steps monitor labor conditions in their overseas supply networks.

In sum, this study supports the view that free-trade agreements create conditioning frameworks that generate downward economic and institutional pressures on the effectiveness of collective bargaining laws. These pressures will also operate in the collective bargaining process itself, often yielding poorer outcomes for unionized workers. More optimistically, our study shows there are avenues for resistance, notwithstanding the attempt through free trade agreements to impose on politics, law and 
social movements the discipline of market forces. In Canada, law , at least temporarily, has proven to be more resistant to those disciplinary forces than many would have anticipated, but it would be a dangerous strategy to rely exclusively on the vagaries of judicial decision-making to resist the growing commodification of labor. The task of successfully organizing political and social movement resistance, however, is a daunting one. 